\title{
Sinemurian biostratigraphy of the Tannscharten section near Reichraming (Lower Jurassic, Schneeberg Syncline, Northern Calcareous Alps)
}

\author{
Petra LUKENEDER ${ }^{1 * *}$ \& Alexander LUKENEDER ${ }^{1)}$ \\ 1) Museum of Natural History Vienna, Burgring 7, 1010 Vienna, Austria; \\ *) Corresponding author: petra.lukeneder@gmx.at
}

\section{UEG}

KEYWORDS

\begin{abstract}
Lower Jurassic ammonites were collected from deep-water limestones of the Tannscharten section, southwest of Reichraming (Northern Calcareous Alps, Upper Austria). The outcrop provides a rich Upper Sinemurian (Lower Jurassic) ammonite fauna of the Allgäu Formation. The area is situated in the westernmost part of the Schneeberg Syncline in the north of the Reichraming Nappe (High Bajuvaric Unit). The ammonite fauna consists of seven different genera, each apparently represented by $1-2$ species. Echioceratids are the most frequent components (Echioceras, Leptechioceras, Paltechioceras), followed by the phylloceratids (Juraphyllites, Partschiceras) and oxynoticeratids (Gleviceras, Paroxynoticeras). Juraphyllites libertus, Partschiceras striatocostatum, Gleviceras paniceum, Echioceras quenstedti, Echioceras raricostatoides, Paltechioceras boehmi, Leptechioceras meigeni, Leptechioceras macdonnelli and Paltechioceras oosteri are new for the Schneeberg Syncline and allow for the first time a detailed biostratigraphy of the Echioceras raricostatum zone. The assemblage is correlated with other faunae from Austria, Germany, United Kingdom, France, Switzerland and Romania. The cephalopod fauna consists of a mix of elements from the Northwest European Province and the Mediterranean Province. The detailed biostratigraphy based on ammonites is presented here.
\end{abstract}

\section{Introduction}

Lower Jurassic pelagic to hemipelagic sediments are known to form a significant element of the northernmost tectonic units of the Northern Calcareous Alps (e.g. Ternberg-, Reichraming-, Frankenfels-, and Lunz- nappes; Tollmann, 1976, 1985; Egger, 1988; Egger and Faupl, 1999; Vašíček and Faupl, 1999; Egger and van Husen, 2011; see also Piller et al., 2004). In the Reichraming Nappe comprising the Lower Jurassic Tannscharten locality, Liassic cephalopod-bearing deposits are recorded in a deepwater limestone facies, the Allgäu Formation (= Lias Fleckenmergel"). Sinemurian sediments of the Allgäu Formation are composed of grey, intensely burrowmottled limestones with intercalated marls and frequent allodapic crinoid limestone layers (Müller, 1987; Egger, 1988; Egger and van Husen, 2011). Deposits of the Allgäu Formation are formed in deeper basins from deep neritic environments (Jacobshagen, 1963, 1965) to bathyal regions (Bernoulli and Jenkyns, 1970).

Lower Jurassic (i.e. Sinemurian) ammonite faunas are rare in the Northern Calcareous Alps. Ammonite occurrences derived from the Allgäu Formation and Adnet limestone (Adnet Group) of the Reichraming Nappe were described by Geyer (1910) and Müller (1987). Together with the lithostratigraphy and geology of the region, Geyer also described a single Ammonites raricostatus from the Adnet limestone near Molln (castle Altpernstein in Upper Austria). Müller reported a late Sinemurian age for the Allgäu Formation (= "Liasfleckenkalke") based on ammonites but without naming taxa. Comparable

ammonite occurrences were described from various regions of Austria and Germany. Meister and Friebe (2003) published on Liassic ammonites from Adnet limestones and Allgäu Formation in the Northern Calcareous Alps of Vorarlberg. Jacobshagen (1965) described ammonites from the Allgäu Formation (= "Jura-Fleckenmergel") of the Wettersteingebirge. Blau and Grün (1995) and Blau (1998) described extensive faunae from the Allgäu Formation of the Upper Austroalpine (Lienz Dolomites, Eastern Tyrol, Carinthia, Austria). Schröder $(1925,1927)$ and Schlegelmilch (1976) figured and described both assemblages from similar ammonite faunas of southern Germany (e.g. Bavarian Alps).

The presented cephalopod fauna (ammonites, belemnites) was collected from marly limestones and limestones of the Allgäu Formation from the Northern Reichraming Nappe in Upper Austria. Fossiliferous Sinemurian outcrops are scarce; hence, well-preserved ammonites are rare from that time slice in the Northern Calcareous Alps. The new fauna increases the knowledge on Sinemurian ammonite assemblages from the Northern Calcareous Alps. No Liassic ammonites were described or figured until now from the Allgäu Formation of the Reichraming Nappe.

The present ammonite occurrence is clearly linked to a facies change in the Upper Triassic carbonate platform of the Reichraming Nappe. Shallow-water deposits (Rhaetian oolites and limestones) are overlain by a deepening sequence of red, condensed Adnet limestones and 
deep-water deposits of the Allgäu Formation. Ammonites were collected from numerous layers in the Lower Jurassic of the Allgäu Formation. A detailed ammonite biozonation of the Lower Jurassic (i.e. late Sinemurian) in the Northern Calcareous Alps is presented. The aim of this study was to better understand the Lower Jurassic environments and facies zonation in the Reichraming Nappe.

The ammonite data were the first step in a detailed biostratigraphic survey of the westernmost part of the Schneeberg Syncline, a tectonical key area in the Reichraming Nappe (Northern Calcareous Alps). More investigations on this important occurrence of the Allgäu Formation will take place within a planned project on Jurassic and Lower Cretaceous climate. The present work forms the base for additional ammonite collections (bed by bed) that will be carried out to precise the exact position of zone, subzone and biohorizon boundaries.

\section{Geographical setting}

The outcrop Tannscharten (1211 m above sea level) is located $3.5 \mathrm{~km}$ west of Reichraming within the Reichraming Nappe in Upper Austria (ÖK 1:50,000, sheet 69 Großraming; Austromap Online 2017; Fig. 1). The succession, comprising the ammonite-bearing beds, is located $50 \mathrm{~m}$ south of the Tannscharten and $500 \mathrm{~m}$ north of the Schneeberg (1244 m). It is exposed on the left side (mountain side) by a forest road construction (private road Kautsch). The exact position of the ammonite occurrences was determined by global positioning system (GPS): N 47 $52^{\prime} 33.80^{\prime \prime}$ and E $14^{\circ} 24^{\prime} 53.40^{\prime \prime}$. The site can only be accessed with permission of the owner Maximilian Kautsch.

\section{Geological background}

The Lower Jurassic Tannscharten section is located in the westernmost part of the Schneeberg Syncline (Egger and Faupl, 1999, Geological map 1:50,000, sheet 69 Großraming; Egger and van Husen, 2011; Fig. 1). The Schneeberg Syncline is the northernmost Jurassic/Cretaceous Syncline

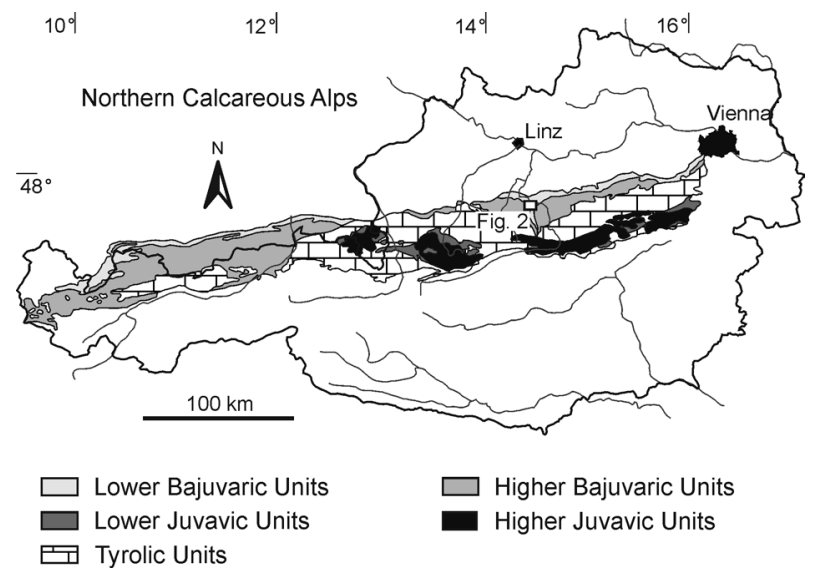

Figure 1: Map of Austria and the Northern Calcareous Alps with their main tectonic subdivisions (Bajuvaric, Tyrolic and Juvavic unit). Indicated is the position of the Tannscharten locality and area of Figure 2 (white rectangle). of the Reichraming Nappe, followed by the Anzenbach Syncline and the Ebenforst Syncline to the south (Fig. 2). The Reichraming Nappe (High Bajuvaric Unit of the Northern Calcareous Alps) is bordered to the north by the Ternberg Nappe, to the east by the Frankenfels Nappe and to the south by the Tyrolic units. The Tannscharten area is situated in a relatively small part along the westernmost border of the Schneeberg Syncline. It appears tectonically isolated from the main area of the Schneeberg Syncline starting $3 \mathrm{~km}$ to the west at Dirnbach. The Schneeberg Syncline (Fig. 2) is typically formed by deposits of the Upper Triassic Kössen Formation (Rhaetian), oolites and limestones (both Rhaetian), the Lower Jurassic Adnet limestone (Liassic) and Allgäu Formation (Liassic), the Middle Jurassic Chiemgau Formation (Dogger) and Vils limestone (Dogger), red Upper Jurassic to Lower Cretaceous limestone (Tithonian-Berriasian) and in the core of the syncline by the Lower Cretaceous Schrambach Formation (Valanginian-Barremian; Egger, 1988; Egger and Faupl, 1999; see also Piller et al., 2004). Important work on regional geology was done by Jacobshagen $(1963,1965)$, Egger (1988), Böhm (1992), Egger and Faupl (1999) and Vašíček and Faupl (1999).

The outcrop is exposed over a length of $80-100 \mathrm{~m}$. It consists of about $50 \mathrm{~m}$ cherty limestones and burrowmottled limestones ("Fleckenmergel", Tollmann, 1976, 1985; Figs. 3, 4) of the Allgäu Formation, intercalated by numerous crinoid-bearing layers (i.e. allodapic limestones). The multiple occurrence of the crinoidal limestone beds are probably caused by intense folding of the Lower Jurassic succession. According to Jacobshagen $(1963,1964)$, the characteristic feature of the Allgäu Formation is intense burrow-mottled, dark-grey limestones with intercalated marls. Based on the definition by the latter author, the Tannscharten section is part of the lower Allgäu Formation (= Ältere Allgäu-Schichten; Jacobshagen, 1963, 1965), ranging from the Hettangian to the Pliensbachian. Blau (1998) interpreted the Allgäu Formation as Lower Jurassic deep-water basin facies. Deposits of the Allgäu Formation overlay fossiliferous (ammonites, foraminifers, crinoids) red limestones (10 m) of the Sinemurian Adnet Formation (Adnet Group). Rhaetian yellowish to grey foraminiferal limestones are underlain by Rhaetian shallow-water oolites (20 m) (Figs. 3, 4).

\section{Material and methods}

\subsection{Fossil material}

The fossils originate from the Lower Jurassic Allgäu Formation at the Tannscharten. 46 ammonite specimens were collected bed by bed, prepared and photographed. The ammonite material is well preserved, though partly fragmented and flattened. Moulds were coated with ammonium chloride before photographing. Original (primary aragonite) shell material was absent. Suture lines were only fragmentary preserved in a few specimens. Additionally, four belemnite specimens and two brachiopods were collected. The material was 

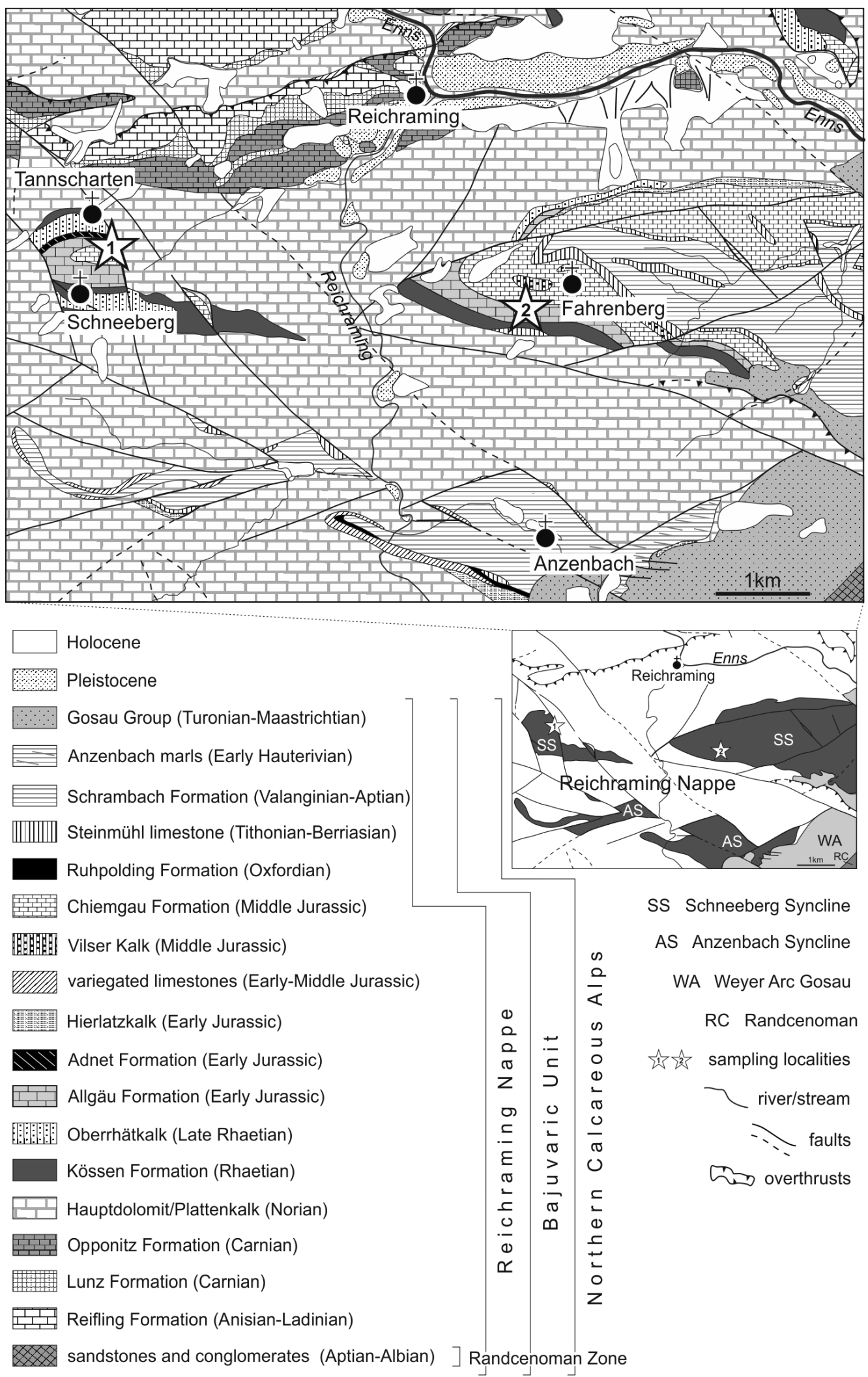

Figure 2: Geological map of the investigated area with position of the sections Tannscharten (star 1) and Fahrenberg (star 2) in the northernmost part of the Northern Calcareous Alps (Upper Austria). Tectonic map shows the regional extent of the Schneeberg Syncline (SS) and Anzenbach Syncline (AS).

stored at the Natural History Museum in Vienna (NHMW 2017/0139/0001-0046). Additional 10 ammonite specimens from the Fahrenberg section were collected by the private collectors Berthold Lumplecker $(n=10$, collection
BL in Großraming) and Fabian Rabl ( $n=12$, collection FR in Bad Kreuzen).

The ammonite assemblage consists of 7 late Sinemurian genera. Echioceratids (Echioceras, Leptechioceras, 

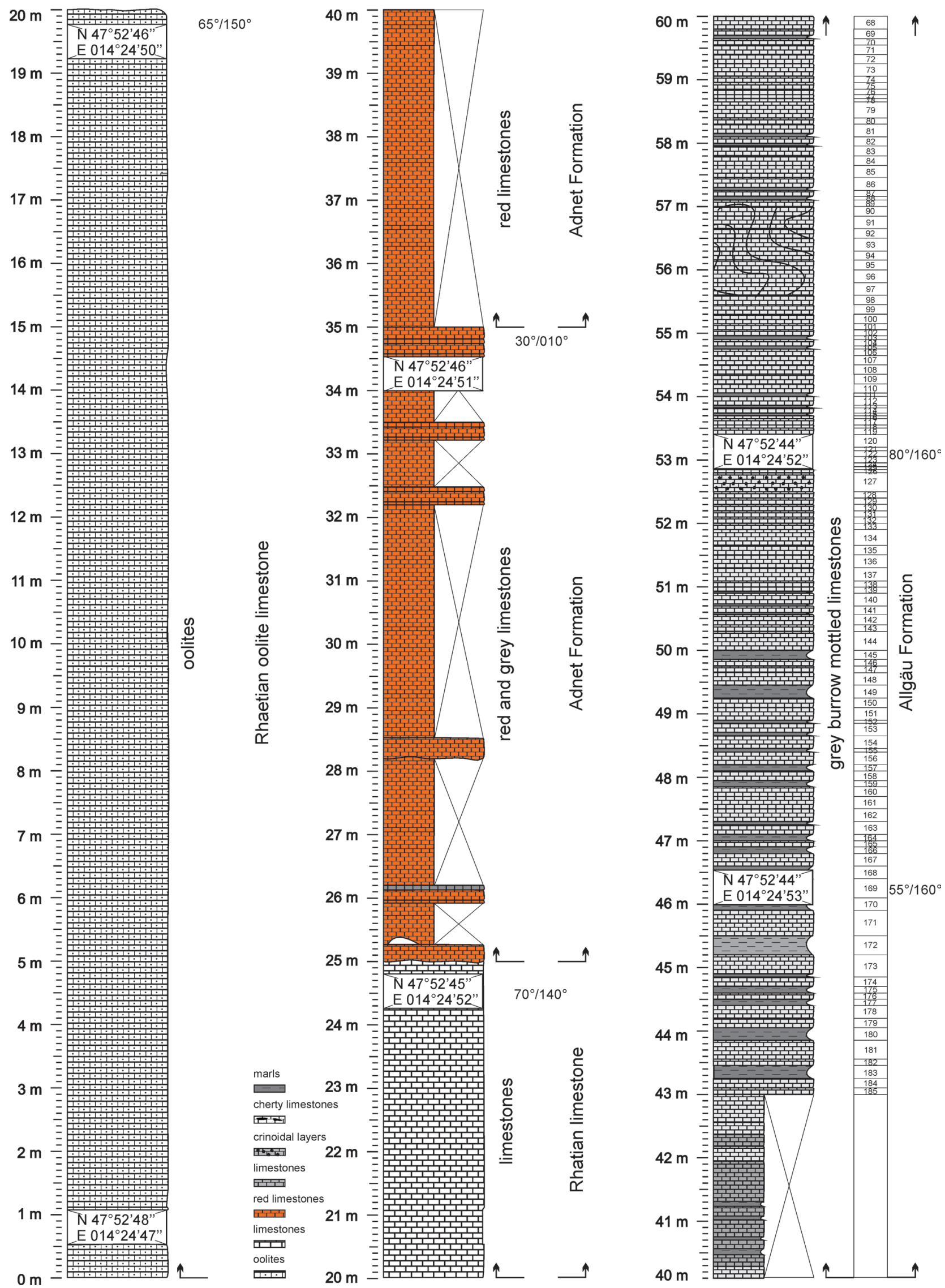

Figure 3: Lower and middle parts of the Tannscharten log with beds 68-185 of the lower Allgäu Formation (at 43-60 m). Rhaetian oolites and limestones are overlain by red limestones of the Jurassic Adnet Formation. 
Sinemurian biostratigraphy of the Tannscharten section near Reichraming (Lower Jurassic, Schneeberg Syncline, Northern Calcareous Alps)
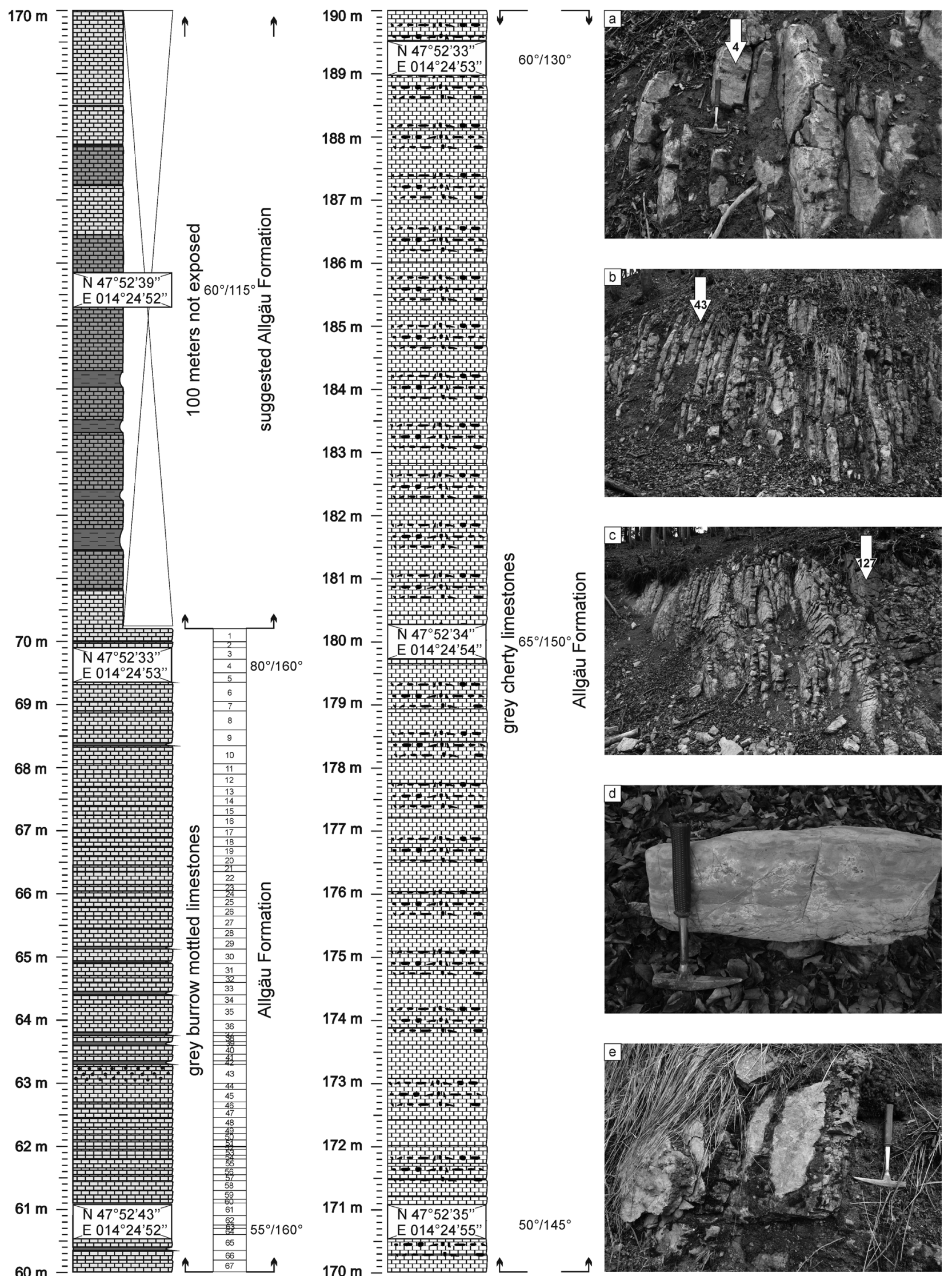

Figure 4: Middle and upper parts of the Tannscharten log with beds 1-67 of the lower Allgäu Formation (at 60-70 m; a, b, c). The marly, silicious and burrow-mottled (d) limestones of the lower Allgäu Formation with indicated beds 4, 34 and 127 are overlain by cherty limestones (e) of the upper Allgäu Formation. 
Paltechioceras) are the most frequent components, followed by the phylloceratids (Juraphyllites, Partschiceras), and oxynoticeratids (Gleviceras, Paroxynoticeras). The cephalopod fauna consists of Euroboreal and Tethyan elements.

\subsection{Morphological parameters}

All morphological parameters (Fig. 5) were measured whorl by whorl on each ammonite specimen to obtain comparable results. For species determination, the number of ribs was counted and parameters such as maximum diameter $(d)$, aperture height (ah), whorl height $(h)$, umbilical width $(u)$, whorl breadth (w) and average distance of each ammonite specimen were measured or, if necessary, extrapolated.

The degree of involution $(h / u)$, whorl compression $(h / w)$, whorl expansion rate (WER) and proportional height $(h / d)$ were calculated. Additionally, presence and shape of a keel and grooves aside, as well as shape and direction of ribs and other characteristic traits, were taken into account for determination.

Abbreviations. $d$, maximum diameter; $h$, whorl height; $h / d$, proportional height; $h / u$, degree of involution; $h / w$, whorl compression; $n$, number of ribs; $u$, umbilical width; $u / d$, proportional umbilical width; $w$, whorl breadth; $w / d$, proportional whorl breadth; $r^{2}$, coefficient of determination; OD, original designation; NCA,

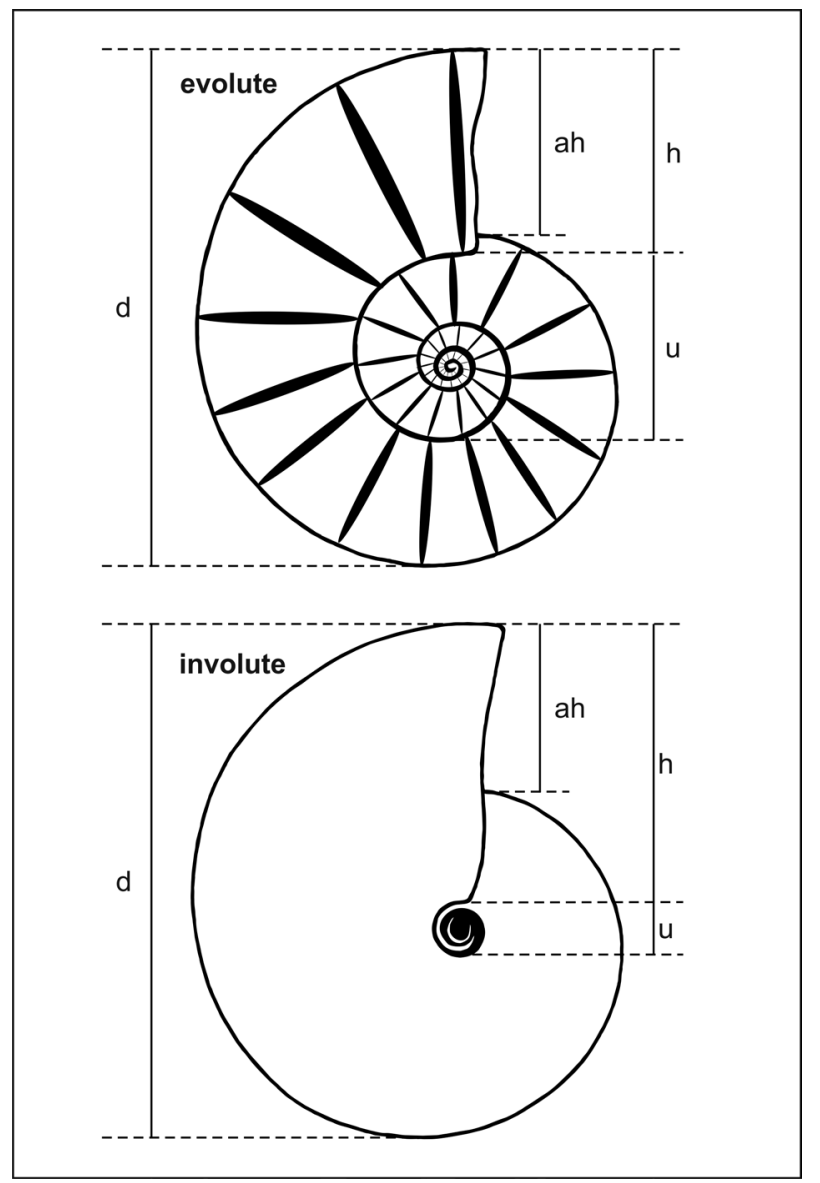

Figure 5: Measured morphological parameters in evolute and involute. $d$, maximum diameter; ah, aperture height; $h$, whorl height; $u$, umbilical width.
Northern Calcareous Alps; NHMW, Natural History Museum Vienna. WER $=[d /(d-a h)]^{2}$ for subdivision of ammonite coiling (after Korn (2000), Klug (2001)). WER standard (Korn 2000): low < 1.60, moderate 1.61-2.0, moderately high 2.01-2.40, high 2.41-2.80 and very high $>2.80$. Average rib distance was calculated from mean of three values.

\subsection{Biostratigraphical background}

The Upper Sinemurian ammonite biozonation with zonal index species is partly shown in Figure 6. According to Page (2003) and Ogg and Hinnov (2012), the Sinemurian stage is subdivided into the following chronozones (named after the ammonite index species, Fig. 6). From the topmost: Upper Sinemurian Echioceras raricostatum, Oxynoticeras oxynotum and Asteroceras obtusum zones; Lower Sinemurian Caenisites turneri and Arnioceras semicostatum zones and Lowermost Sinemurian Arietites bucklandi zone. Zonation is quite varying in the Northwest European Province (United Kingdom, Ireland, France, Northern Germany, Switzerland and others) and the Mediterranean Province (Austria, Southern Germany and Italy; Page 2003). We did not follow the statement of Page (2003, p. 36) that Echioceras raricostatoides is a junior synonym of $E$. raricostatum.
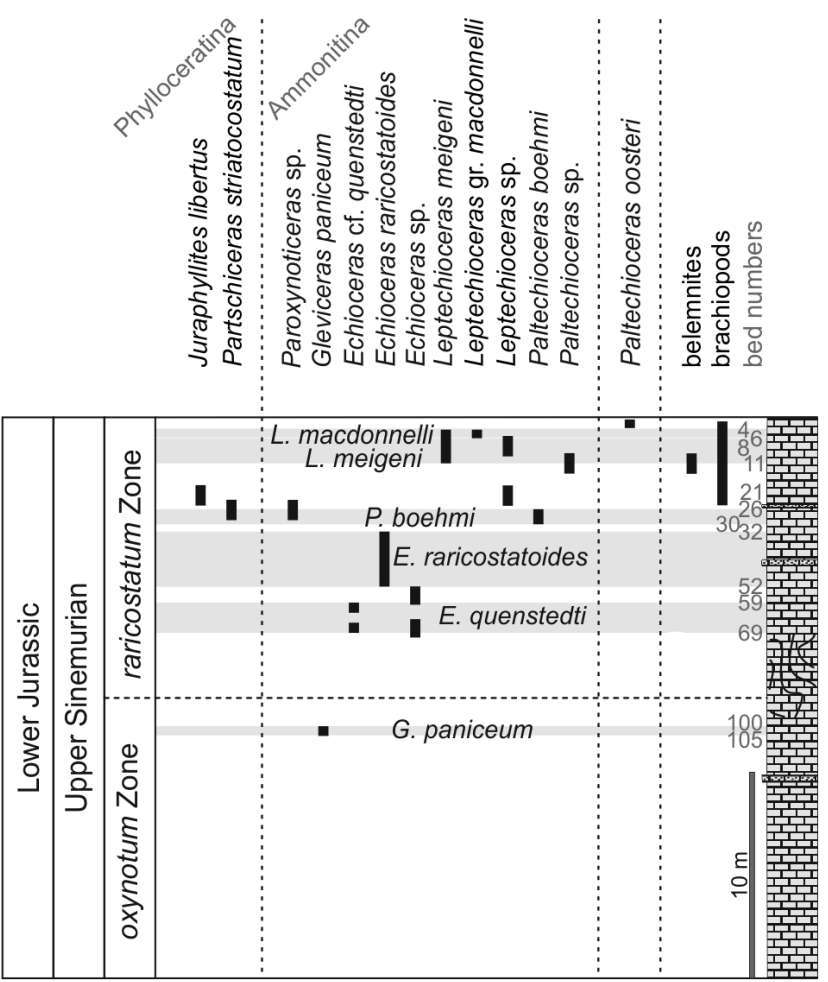

Figure 6: Ranges of the ammonite taxa occurring in the Tannscharten section with indicated biostratigraphic ammonite zonation from the Lower Jurassic (Upper Sinemurian). Occurrence of black range bars of ammonite taxa in the section. Paltechioceras oosteri derives from the Fahrenberg locality of the same syncline. Assumed biohorizons (Gleviceras paniceum, Echioceras quenstedti, Echioceras raricostatoides, Paltechioceras boehmi, Leptechioceras meigeni, Leptechioceras macdonnelli) are highlighted in grey. 
The chronozones are subdivided into subzones and biohorizons (see Blau, 1998; Fig. 6). The E. raricostatum zone is divided into subzones from the bottom to top as follows: Crucilobiceras densinodulum, E. raricostatum, Leptechioceras macdonnelli and Paltechioceras aplanatum. The O. oxynotum zone starts with the lower Oxynoticeras simpsoni subzone and the upper $O$. oxynotum subzone. Blau and Meister (2000) proposed further 41 horizons for the Upper Sinemurian. More sampling and additional material would be needed to adopt these detailed subdivisions to the fauna from the Tannscharten locality.

For a concise international correlation, ammonite biogeographical provinces have to be considered. According to Schlegelmilch (1976), the $C$. densinodulum subzone and the $E$. raricostatum subzone are not distinguishable in Southern Germany. This might be also the case in the High Bajuvaric Units of the Northern Calcareous Alps. Page (2003) listed all zones and horizons detected so far in the Mediterranean province. The lower Allgäu Formation consisting of bioturbated limestones and intercalated marls embraces both the 0 . oxynotum zone and the E. raricostatum zone (Jacobshagen, 1965).

\section{Systematic Palaeontology}

All collected specimens belong to the suborders Phylloceratina and Ammonitina (class Cephalopoda, subclass Ammonoidea). For the ammonite determination, publications of Schlegelmilch (1976), Blau (1998) and Meister and Friebe (2003) were used. The ammonite systematics and taxonomy were adopted and compared with those in papers by the latter authors. In the following, except one specimen of Paroxynoticeras, only specimens that are identified on a species level, and thus of biostratigraphical importance, are described and figured (Figs. 7, 8):

Class Cephalopoda Cuvier, 1797

Order Ammonoidea Zittel, 1884

Suborder Phylloceratina Arkell, 1950

Family Phylloceratidae Zittel, 1884

Genus Partschiceras Fucini, 1923

Type of species: Ammonites Partschi Stur, 1851 (nomen nudum); = Partschiceras striatocostatum (Meneghini, 1853)

\section{Partschiceras striatocostatum (Meneghini, 1853)} Fig. 7a, b; Tab. 1

1851 Ammonites partschi - Stur, p. 26 (nomen nudum) *1853 Ammonites striatocostatus - Meneghini, p. 28 1927 Phylloceras Partschi Stur - Schröder, p. 122 1991 P. striatocostatum (Meneghini, 1853) - Blau, p. 177, pl. 2, figs., 2, 3 1998 P. striatocostatum (Meneghini, 1853) - Blau, p. 196, pl. 1, figs. 8, 9, 14 (cum. syn.)

1999 P. striatocostatum (Meneghini, 1853) - Rakús, p. 348, text-fig. 8, pl. 1, figs. 9-11
2000 P. striatocostatum (Meneghini, 1853) - Joly, p. 35, text-figs. 56, 57; pl. 4, fig. 5

2003 P. gr. striatocostatum (Meneghini, 1853) Meister and Friebe, p. 23, pl. 1, figs. 8, 13; pl. 2, figs. 4, 7 (cum. syn.)

Number of specimens: One specimen from the Tannscharten section (NHMW 2017/0139/0001)

Description: One half of a specimen is preserved. The involute specimen exhibits an oval, elongated whorl section with a well-rounded venter and subrounded flanks. Strong, primary prorsiradiate ribs start at the mid of flank and cross the venter without interruption. Very fine, fibrous ribs are overprinting the primary ribs. The umbilicus is narrow with a steep wall. About 33 primary ribs were counted on the last half whorl. The average rib distance is $2.64 \mathrm{~mm}$. The high WER value of 2.52 reflects the fast whorl height growth. The specimen represents a phragmocone with the suture line visible throughout. According to Blau (1998), the flanks are slightly arched and the maximal width can be observed near the centre of the flanks. For a more detailed description, see Wiedenmayer (1977) and Braga and Rivas (1987). Meister and Friebe (2003) stated that $P$. striatocostatum is easily to distinguish from similar species such as Partschiceras proclive (Rosenberg), Partschiceras sturi (Stur) and Partschiceras anonymum (Haas) by their rursiradiate ribbing. The related species Partschiceras tenuistriatum (Meneghini) shows much finer ribbing. P. stu$r i$ and $P$. anonymum are often treated to be synonymous with $P$. striatocostatum and $P$. tenuistriatum (see Braga and Rivas, 1987; Blau, 1998).

\section{Measurements:}

Type/

Inv. Nr. $\quad d \quad h \quad w \quad u \quad$ ah $h / w h / d \quad h / u \quad$ u/d $\quad$ w/d WER NHMW

2017/ $74.5043 .33 \quad 20.55 \quad 5.92 \quad 27.53 \quad 2.110 .58 \quad 7.320 .080 .282 .52$

0139/ $74.5043 .33 \quad 20.55 \quad 5.92 \quad 27.532 .11 \quad 0.58 \quad 7.32 \quad 0.08 \quad 0.28 \quad 2.52$ 0001

Occurrence and stratigraphic range: At the Tannscharten section, $P$. striatocostatum appears in bed 26, part of the E. raricostatum zone. The species occurs in the entire Tethyan realm and southern Northwest European Province (Caucasus Basin; Meister and Friebe, 2003). According to Blau (1998), this species has a stratigraphic range from the early Sinemurian $(A$. semicostatum zone) to the early Toarcian Dactylioceras tenuicostatum zone. Blau and Meister (1991) reported $P$. striatocostatum from the late Pliensbachian Amaltheus margaritatus zone (Amaltheus stokesi - A. margaritatus and Amaltheus subnodosus subzones). Meister and Friebe (2003) mentioned a Sinemurian to Pliensbachian age for $P$. striatocostatum. The lectotype specimen redescribed by Rakús (1999) from Hirlatz Mountain is from the O. oxynotum zone.

Family Juraphyllitidae Arkell, 1950

Genus Juraphyllites Müller, 1939 


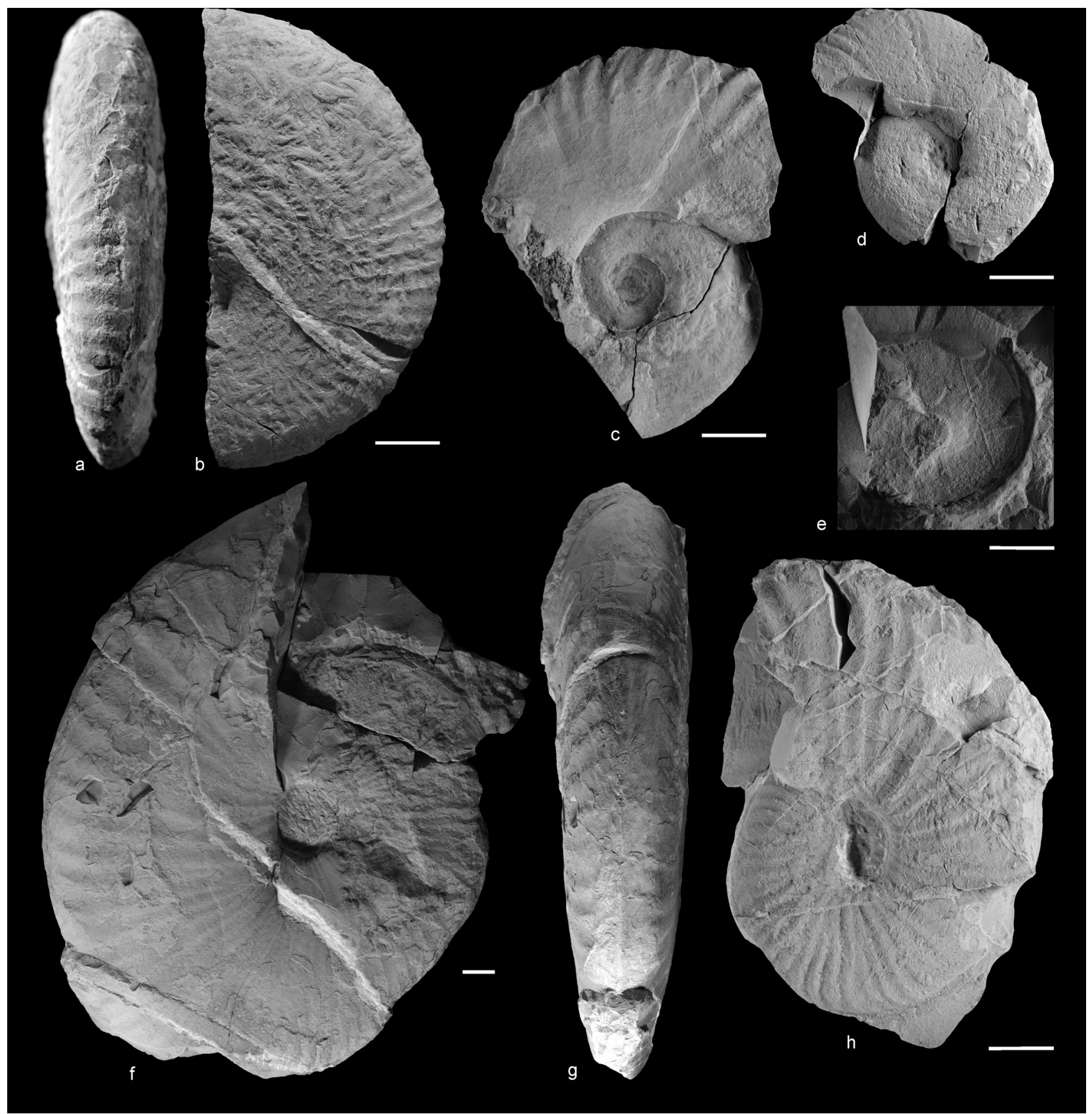

Figure 7: Ammonite fauna from the late Sinemurian Tannscharten section. $\mathbf{a}$, b Partschiceras striatocostatum (Meneghini), ventral and lateral views, NHMW 2017/0139/0001. c Juraphyllites libertus (Gemmellaro), lateral view, BL 2017/0001. d J. libertus (Gemmellaro), lateral view, NHMW 2017/0139/0002. e Paroxynoticeras sp. (imprint), lateral view, NHMW 2017/0139/0003. f, g Gleviceras paniceum (Quenstedt), lateral and ventral views, NHMW 2017/0139/0004. h G. paniceum (Quenstedt), lateral view, NHMW 2017/0139/0005. White scale bars represent $1 \mathrm{~cm}$.

\section{Type of species: Phylloceras diopsis Gemmellaro (1884); OD}

\section{Juraphyllites libertus (Gemmellaro, 1884)}

Fig. 7c, d; Tab. 2

*1884 Phylloceras libertum - Gemmellaro, p. 168, pl. 2, figs. $1-5$

1927 Rhacophyllites libertus (Gemmallaro) - Schröder, p. 143 , pl. 8 , figs. a, b

1998 J. libertus (Gemmellaro, 1884) - Blau, p. 200, textfigs. 18 , 19; p. 255 , pl. 1, figs. $4,11,18$ (cum. syn.)
2000 J. libertus (Gemmellaro, 1884) - Joly, p. 29 2003 J. libertus (Gemmellaro, 1884) - Meister and Friebe, p. 25, pl. 2, fig. 6 (cum. syn.)

Number of specimens: Two specimens, one from the Tannscharten section (NHMW 2017/0139/0002) and the other from the Fahrenberg section (BL 2017/0001)

Description: The semi-involute and discoidal specimen appears with almost flat to subrounded flanks and a rounded venter. The last whorl encompasses the previous one down to one half. The early whorls seem to be smooth, whereas the sculpture of the last, third whorl 


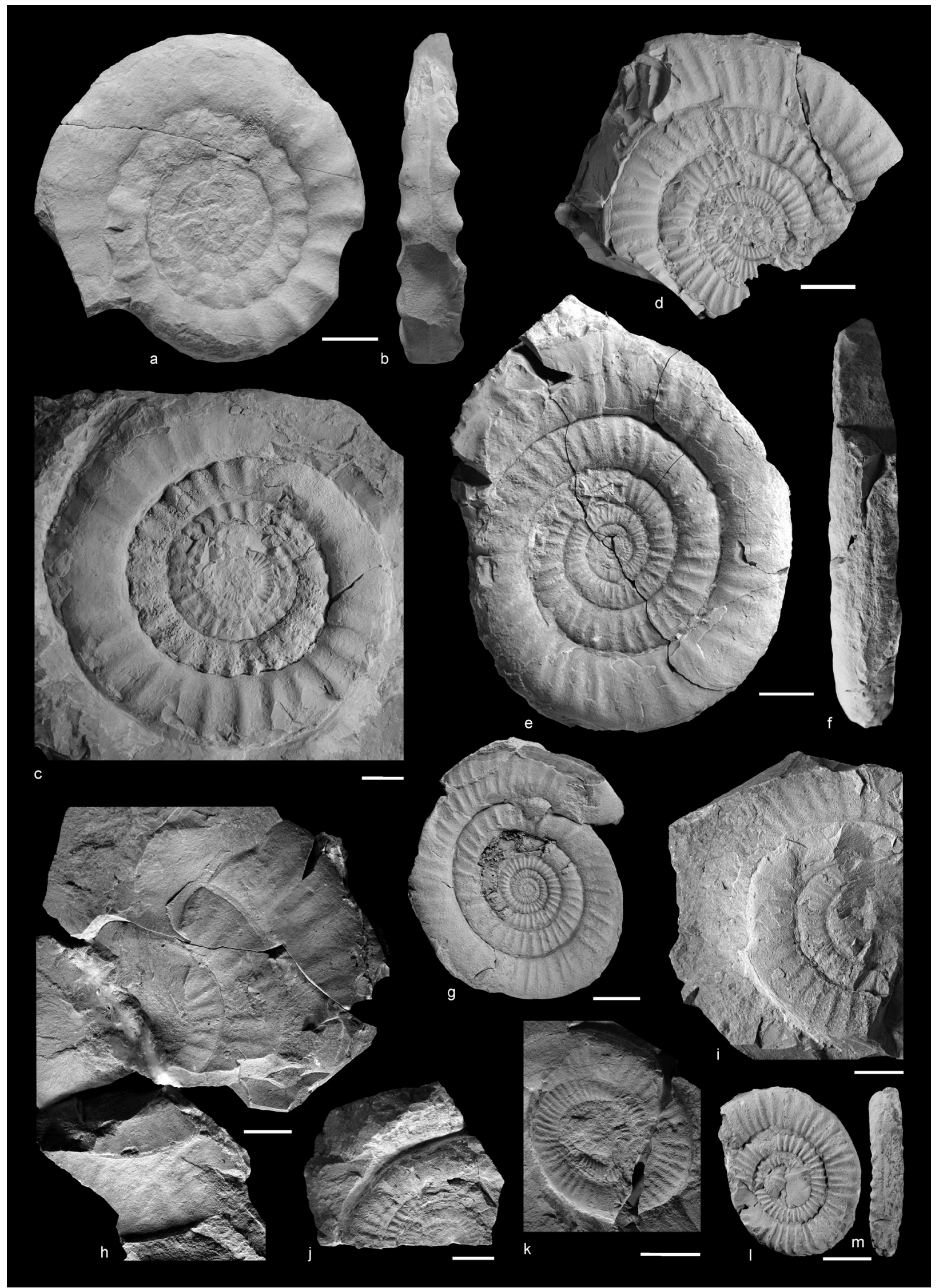

Figure 8: Ammonite fauna from the late Sinemurian Tannscharten and Fahrenberg sections. a, b Echioceras raricostatoides Vadász, lateral and ventral views, NHMW 2017/0139/0006. c Echioceras quenstedti (Schafhäutl), lateral view, NHMW 2017/0139/0011. d Leptechioceras meigeni (Hug), lateral view, NHMW 2017/0139/0014. e, f L. meigeni (Hug), lateral and ventral views, NHMW 2017/0139/0015. g L. meigeni (Hug), lateral view, BL $2017 / 0002$. h, i, j Leptechioceras gr. macdonnelli (Portlock), lateral view, NHMW 2017/0139/0024-0026. k Paltechioceras boehmi (Hug, 1899), lateral view, NHMW 2017/0139/0030. I, m Paltechioceras oosteri (Dumortier), lateral and ventral views, BL 2017/0010. White scale bars represent $1 \mathrm{~cm}$. 
shows two major elements. Fine, prorsiradiate ribbing sets in from mid-flank and crosses the venter slightly projected without interruption. Three straight and strongly prorsiradiate constrictions are visible on the final whorl half. The constrictions start from the steep umbilical wall, pass the venter and form an angle (approximately $10^{\circ}-20^{\circ}$ ) with the finally stronger external ribbing. The first constriction marks the beginning of the body chamber, which is also marked by the last visible suture line. An average rib distance of $1.58 \mathrm{~mm}$ was measured on a specimen (NHMW 2017/0139/0002; Fig. 7d) with a diameter of $44.9 \mathrm{~mm}$. The specimen appears with a WER value of 2.53 , hence doubling the whorl height within the last whorl. The presence of constrictions is the main difference to the similar Juraphyllites diopsis (Gemmellaro). The stronger ribbing in the related species Juraphyllites nardii (Meneghini) starts below the mid-flank in contrast to J. libertus.

\section{Measurements:}

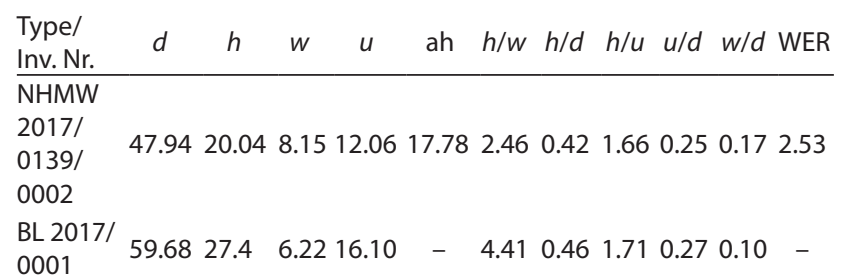

Occurrence and stratigraphic range: At the Tannscharten section, J. libertus appears in bed 21, part of the $E$. raricostatum zone. The species occurs in the entire Tethyan realm, the southern Northwest European Province (Caucasus Basin) and the Euroboreal realm (Meister and Friebe, 2003). According to Meister and Friebe (2003), J. libertus has a stratigraphic range from the early Plienbachian to the early Toarcian. Blau (1998) reported the species from the older E. raricostatum zone up to the $P$. aplanatum zone. Wissner (1958) stated an age of O. oxynotum zone. Specimens of J. libertus of late Pliensbachian were reported by Wiedenmayer (1977).

Suborder Ammonitina Hyatt, 1889

Family Oxynoticeratidae Hyatt, 1875

Genus Paroxynoticeras Pia, 1914

Type of species: Ammonites salisburgensis Hauer, 1856; designated by Spath (1926)

\section{Paroxynoticeras sp.}

Fig. 7e; Tab. 3

Number of specimens: One specimen (NHMW 2017/0139/0003)

Description: The involute, oxycone specimen shows an elliptic whorl section with the maximum whorl breadth at mid-flank. The last whorl half encompasses the body chamber. The umbilicus is moderately open and bordered by a steep and short umbilical wall.
The mould shows an almost smooth stage (see Blau, 1998). The most prominent and best-known species is Paroxynoticeras salisburgense (Hauer), and after Pia (1914), P. salisburgense can be distinguished from all other species by the weak sculpture up to a total loss of ribbing in ontogeny.

\section{Measurements:}

\begin{tabular}{l}
$\begin{array}{l}\text { Type/ } \\
\text { Inv. Nr. }\end{array}$ \\
\hline NHMW
\end{tabular}

Occurrence and stratigraphic range: At the Tannscharten, Paroxynoticeras sp. occurs in bed 26, a part of the E. raricostatum zone. Pia (1914) proposed a Lias $\beta$ (Sinemurian) age for $P$. salisburgense. Many specimens of Paroxynoticeras (i.e. P. salisburgense) are known from the $O$. oxynotum zone (i.e. O. oxynotum subzone) of the late Sinemurian in the Tethyan realm (Blau, 1998; Rakús, 1999).

\section{Genus Gleviceras Buckman, 1918}

Type of species: Gleviceras glevense Buckman, 1918; OD

\section{Gleviceras paniceum (Quenstedt, 1884)}

Fig. $7 f, g, h ; T a b .4$

*1885 Ammonites paniceus - Quenstedt, p. 163, pl. 21, figs. 27-29

1906 Oxynoticeras paniceum - Pompeckj, p. 266, number 3

1914 O. paniceum Quenst. spec. - Pia, p. 33, pl. 6, fig. 3

1976 G. paniceum (Quenstedt, 1884) - Schlegelmilch, p. 60 , pl. 23, fig. 2 (cum. syn.)

Number of specimens: Two specimens (NHMW 2017/0139/0004-5)

Description: The involute shell is sub-oxycone (see Meister, 2006). The umbilical wall is steep and short. Specimens show strong primary ribs that start at umbilical seem. Approximately 60 ribs appear on the last whorl of the larger specimen, with an average rib distance of $4.72 \mathrm{~mm}$. The ribbing style typically changes during ontogeny in both specimens. Ribbing starts with strong, sharp and bifurcating ribs on the inner whorls and changes to single ribs in the adult stages. Ribs are slightly rursiradiate, changing in adults to prorsiradiate directions. Bifurcation is at the lower third side of the flanks and ends at the ventral side with a strong projection at a smooth band on both sides of the accented keel. The species shows maximum diameters of up to $208 \mathrm{~mm}$, which is in accordance with the observations made by Schlegelmilch (1976). The suture line is partly visible, as the smaller specimen (Fig. 7h) exhibits almost an entire 
phragmocone, whereas the last half whorl of the large specimen (Fig. 7f, g) is formed by the body chamber. The smaller specimen shows a WER value of 2.97, whereas the larger specimen shows a decreased WER value of 2.07, hence a decreasing trend of whorl height growth within the last whorl. Both specimens, the large (NHMW 2017/0139/0004) and the small (NHMW 2017/0139/0005; Fig. 7h), show a partly preserved, distinct and sharp keel up to $3 \mathrm{~mm}$ high. According to Meister and Friebe (2003) and Blau (1998) (see both authors also for other species descriptions), G. paniceum exhibits a well-expressed ornamentation that distinguishes it from other related species such as Gleviceras lotharinghium (Reynes) and Gleviceras boucaultianum (Dumortier).

\section{Measurements:}

\begin{tabular}{l}
$\begin{array}{l}\text { Type/ } \\
\text { Inv. Nr. }\end{array}$ \\
\hline NHWW
\end{tabular}

NHMW

2017/ 197.4580 .5544 .4520 .9860 .051 .810 .393 .840 .100 .392 .07

0004

NHMW

$\begin{array}{llllllllllll}2017 / & 66.73 & 33.3 & 16.0 & 10.5 & 28.41 & 2.15 & 0.50 & 3.17 & 0.16 & 0.23 & 2.97\end{array}$

0005

Occurrence and stratigraphic range: At the Tannscharten, G. paniceum (Quenstedt) occurs in beds 100 and 105, which are part of the O. oxynotum zone. According to Schlegelmilch (1976), G. paniceum appears in the O. oxynotum zone, whereas Pia (1914) mentioned that this species occurs earlier in the late Sinemurian Asteroceras obtusum zone.

Family Echioceratidae Buckman, 1913

Genus Echioceras Bayle, 1878

Type of species: A. raricostatus Zieten, 1831

\section{Echioceras raricostatoides Vadász, 1908}

Fig. 8a, b; Tab. 5

1907 Arietites raricostatoides nov. sp. - Vadász, p. 358

* 1908 A. raricostatoides, nov. sp. - Vadász, p. 373, fig. 26

1973 E. raricostatoides (Vadász) - Getty, p. 13, pl. 1, fig 12

1976 E. raricostatoides (Vadász, 1908) - Schlegelmilch, p. 51 , pl. 21 , fig. 11

1998 E. raricostatoides (Vadász, 1908) - Blau, p. 206, pl. 4, figs. 3-8 (cum. syn.)

2002 Echioceras sp. - Plöchinger and Karanitsch, p. 87, fig. 152

2005 E. raricostatoides (Vadász, 1908) - Tibuleac, p. 485, pl. 3, fig. 2

2007 E.? raricostatoides (Vadász, 1908) - Tomas and Pálfy, p. 247 , fig. $5 \mathrm{~g}-\mathrm{h}, \mathrm{j}-\mathrm{k}$

Number of specimens: Five specimens (NHMW 2017/0139/0006-10)
Description: The evolute specimens show a fastigiate and rounded whorl section. The string like keel occurs throughout ontogeny, without grooves aside. Smooth areas accompany the keel throughout. The primary ribs are strong and slightly prorsiradiate and raricostate, thickening ventrolaterally. On the adult body chamber, the ribs appear with almost a ventral swelling. Spacing of ribs changes from narrow to wide at approximately 10-12 mm diameter. According to Blau (1998), the transition to a wide-spaced ribbing stage is around $5 \mathrm{~mm}$ diameter. The difference may be the result of the diagenetic compression of the inner whorls in the figured specimen (Fig. 8a, b). No suture line is visible. $E$. raricostatoides is similar to Echioceras quenstedti (Schafhäutl), but ribs end up in swellings. Less primary ribs at comparable same diameter occur in E. raricostatoides with 20 on the last whorl and 27 in E. quenstedti. The average rib distance is $3-5 \mathrm{~mm}$ in E. raricostatoides on the final whorl and 2-3 $\mathrm{mm}$ in E. quenstedti. The whorl section in the related $E$. raricostatum (Zieten) is rectangular (flat venter) and not rounded as in E. raricostatoides (Schlegelmilch, 1976), but sometimes it is hard to distinguish.

\section{Measurements:}

\begin{tabular}{|c|c|c|c|c|c|c|c|c|c|c|c|}
\hline $\begin{array}{l}\text { Type/ } \\
\text { Inv. Nr. }\end{array}$ & $d$ & $h$ & $w$ & $u$ & ah & $h / w$ & $h / d$ & $h / u$ & $u / d$ & $w / d$ & WER \\
\hline $\begin{array}{l}\text { NHMW } \\
2017 / \\
0139 / \\
0006\end{array}$ & 56.35 & 12.55 & 7.36 & 33.69 & - & 1.71 & 0.22 & 0.37 & 0.60 & - & - \\
\hline $\begin{array}{l}\text { NHMW } \\
2017 / \\
0139 / \\
0008\end{array}$ & 65.63 & 14.52 & 9.04 & 46.23 & - & 1.61 & 0.22 & 0.31 & 0.70 & - & - \\
\hline
\end{tabular}

Occurrence and stratigraphic range: At the Tannscharten, E. raricostatoides Vadász, 1908 occurs in beds $32-52$, which are part of the E. raricostatum zone. This species appears in the entire Tethyan realm and is restricted to a short stratigraphic range in the late Sinemurian $E$. raricostatum zone ( $E$. raricostatum subzone; Blau, 1998; Blau and Meister, 2000; Tibuleac, 2005). Blau (1998) mentioned an even more restricted occurrence from the Lienz Dolomites (Upper Austroalpine, Austria) as E. raricostatoides horizon in the lower $E$. raricostatum subzone.

\section{Echioceras quenstedti (Schafhäutl, 1847)}

Fig. 8c; Tab. 6

*1847 Ammonites quenstedti m. - Schafhäutl, p. 810, pl. 8, fig, 1 ; pl. 15, fig. 9

1973 E. quenstedti (Schafhäutl) - Getty, p. 20, pl. 2, fig. 7 1989 E. quenstedti (Schafhäutl) - Dommergues and Meister, p. 464, pl. 1, figs. 4-17

1998 E. quenstedti (Schafhäutl, 1847) - Blau, p. 205, pl. 4, figs. 1, 2 (cum. syn.)

2003 Echioceras gr. quenstedti (Schafhäutl, 1847) - Meister and Friebe, p. 36, pl. 10, figs. 6-8; pl. 11, figs. 1, 2 
Number of specimens: Three specimens (NHMW 2017/0139/0011-13)

Description: The evolute specimens show a fastigiate and rounded whorl section (subcircular after Meister and Friebe, 2003). The string-like keel (feeble keel) occurs throughout ontogeny, without grooves or sulci aside. Smooth areas accompany the keel throughout. The primary ribs are strong, sharp and radiate to slightly prorsiradiate and raricostate. In contrast to E. raricostatoides, the ribs are equal in thickness from the rounded umbilical edge up to the venter. Ventral endings of primary ribs do not end up in swellings. Ribbing is not as strong as in $E$. raricostatoides. On the adult body chamber, very fine ribbing (may be growth lines), almost not visible, intercalates the primary ribs. Spacing of ribs changes from narrow to wide at approximately $15 \mathrm{~mm}$ diameter (see also Dommergues and Meister, 1989). The entire specimen (NHMW 2017/139/0011) shows a low WER value of 1.42 mirroring the slow increasing trend of whorl height growth within the last whorl. No suture line is visible. A total of 27 primary ribs occur in E. quenstedti compared to E. raricostatoides with 20 ribs on the last whorl at the same diameter. The average rib distance appears in E. quenstedti with 2-3 $\mathrm{mm}$ and in E. raricostatoides on the final whorl, slightly increased to 3-5 $\mathrm{mm}$. The whorl section in the related E. raricostatum (Zieten) is rectangular (flat venter) and not rounded as in E. quenstedti (Schafhäutl, 1847), sometimes hard to distinguish. Numerous additional species such as Echioceras aeneum Truman and Williams, Pleurechioceras typicum Buckman and Echioceras rhodanicum Buckman were synonymized with $E$. quenstedti (Schafhäutl, 1847) by Blau (1998) and earlier. Getty (1972) placed Echioceras laevidomus (Quenstedt), Echioceras parvum Truman and Williams, Echioceras concinnum Truman and Williams and Echioceras declivis Truman and Williams in the synonymy of E. quenstedti Schafhäutl (1847).

\section{Measurements:}

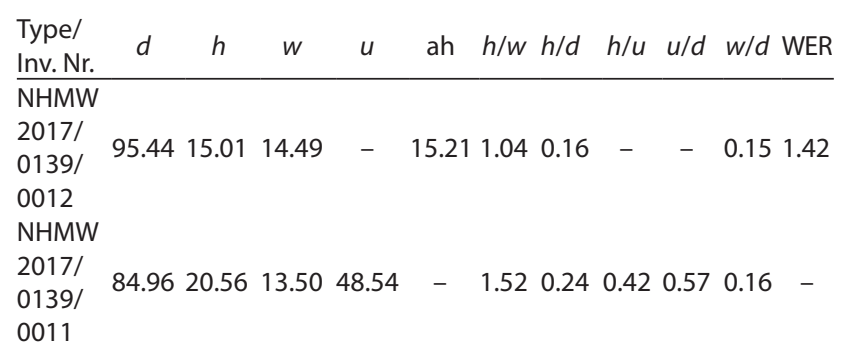

Occurrence and stratigraphic range: At the Tannscharten, E. quenstedti (Schafhäutl, 1847) occurs in beds 59-69, which are part of the E. raricostatum zone. According to Dommergues and Meister (1989), Blau (1998) and Meister and Friebe (2003), E. quenstedti has a shortstratigraphicrangeatthebaseofthelateSinemurian E. raricostatum zone (E. raricostatum subzone) within the lowermost E. quenstedti biohorizon. According to Meister and Friebe (2003), E. quenstedti is mostly known from the Alps (Subbriançonnais and Upper Austroalpine Units).

\section{Genus Leptechioceras Buckman, 1923}

Type species: Ammonites macdonnelli Portlock, 1843

\section{Leptechioceras meigeni (Hug, 1899)}

Fig. 8d-g; Tab. 7

\author{
*1899 Ammonites meigeni - Hug, p. 18, pl. 11, figs. 2, 2a, \\ $3,3 a$ \\ 1987 L. meigeni (Hug 1899) - Schlatter, p. 1122, text-figs. 1, \\ b, c; pl. 1, fig. 4a, b \\ 1989 L. meigeni (Hug, 1899) - Dommergues and Meister, \\ p. 465 , pl. 3, figs. $3-4$ \\ 1998 L. meigeni (Hug, 1899) - Blau, p. 219, pl. 6, figs. 3, \\ 5-15; pl. 7, figs. 1-11; pl. 8, figs. 1-8 (cum. syn.) \\ 2000 L. meigeni (Hug) - Blau et al., p. 268, figs. 5.2, 6.2, 6.4 \\ 2003 L. meigeni (Hug) - Edmunds et al., p. 69, figs. 3.1, 3.2, \\ 3.3 \\ 2003 L. gr. meigeni (Hug, 1899) - Meister and Friebe, p. 38, \\ pl. 11, figs. 5, 9 (cum. syn.) \\ 2005 L. meigeni (Hug, 1899) - Tibuleac, p. 485, pl. 3, fig. 5
}

Number of specimens: Fourteen specimens (NHMW 2017/0139/0014-23; BL 2017/0002-0005)

Description: The very evolute specimens exhibit a fastigiate, elliptic and slightly compressed whorl section; the keel is sharp and appears throughout ontogeny. Smooth areas (not sulci) run on both sides of the keel. The primary ribs are strong and sharp, more radiate on inner whorls and slightly to strong prorsiradiate in adult stages. The ribs are equal in thickness from the rounded umbilical edge over the rounded flanks up to the smooth area on the venter. Specimens reach a maximum diameter of approximately $77 \mathrm{~mm}$. On the most complete specimen (Fig. 8e, f), approximately 42 ribs were counted on juvenile whorls (5th whorl) at a diameter of $20 \mathrm{~mm}$. On the final whorl, 37 ribs were counted at a diameter of $77 \mathrm{~mm}$. Specimen Fig. 8d shows approximately 46 ribs on juvenile whorls (4th whorl) at a diameter of $15 \mathrm{~mm}$. On the penultimate half whorl, 26 ribs were counted at a diameter of $48 \mathrm{~mm}$. The number of ribs decreases slowly but steadily. Both specimens (NHMW 2017/0139/0014 and 0015; 8d and 8 e) show a very low WER value of 1.43 and 1.45 , mirroring the slow increasing trend of whorl height growth on the final whorl. No suture line is visible. Our specimens are quite similar to those shown in Blau (1998) from the Lienz Dolomites. Blau (1998) reported them as quite variable in ribbing, from 15 to 22 primary ribs at the same diameter. L. meigeni from the Tannscharten section shows a high variability in number and development of the ribs (straight to slightly curved; specimen $8 \mathrm{~d}$ has 56 ribs on the last whorl with an average rib distance of $3.41 \mathrm{~mm}$, while specimen $8 \mathrm{~g}$ has 44 ribs on the last whorl with a rib distance of $4.13 \mathrm{~mm}$ ). The related Leptechioceras hugi (Buckman) has finer and radially oriented ribs throughout the ontogeny (Schlatter, 1991). Blau (1998) concluded that L. meigeni shows 
highly variable intraspecific ribbing values in quantity and thickness and subsequently synonymized L. hugi with L. meigeni.

\section{Measurements:}

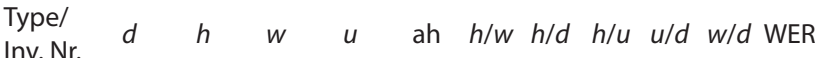
NHMW $\begin{array}{llllllllllll}2017 / & 84.07 & 14.90 & 8.89 & 48.88 & 14.34 & 1.68 & 0.18 & 0.30 & 0.58 & 0.11 & 1.45\end{array}$ 0014

NHMW

2017/ $83.3618 .3713 .5950 .8415 .851 .350 .22 \quad 0.360 .610 .161 .52$ $0139 /$ 0007

Occurrence and stratigraphic range: At the Tannscharten, L. meigeni (Hug) occurs in beds 6-11, which are part of the E. raricostatum zone. L. meigeni occurs in the Tethyan realm and Euroboreal realm in the late Sinemurian E. raricostatum zone (L. macdonnelli subzone; Schlatter, 1987; Blau, 1998; Meister and Friebe, 2003; Tibuleac, 2005)

\section{Leptechioceras gr. macdonnelli (Portlock, 1843)}

$$
\text { Fig. 8h, i, j; Tab. } 8
$$

*1843 Ammonites macdonnelli - Portlock, p. 134, pl. 29A, fig. 12

1927 Vermiceras Macdonelli Portl. - Schröder, p. 183, pl. 9, figs. $13 a, b, c$

1976 L. macdonnelli (Portlock, 1843) - Schlegelmilch, p. 51, pl. 21, fig. 13

1986 L. macdonnelli (Portlock) - Reid and Bancroft, p. 46, fig. $2 \mathrm{~J}, \mathrm{~K}$

1998 L. macdonnelli (Portlock, 1843) - Blau, p. 217, pl. 8, figs. 9-10; p. 271, pl. 9, figs. 1-5, 7, 9-18; p. 281, pl. 14, fig. 5

1998 L. cf. macdonnelli (Portlock, 1843) - Blau, p. 219, pl. 9 , figs. 6,8

2000 L. macdonnelli (Portlock, 1843) - Blau et al., p. 267, figs. 6.3, 10.1, 10.4

2003 L. macdonnelli (Portlock) - Edmunds et al., p. 68

Number of specimens: Six specimens (NHMW 2017/0139/00024-29)

Description: The very evolute specimens show a fastigiate and subrounded whorl section. The string-like keel (feeble keel) occurs throughout ontogeny, without grooves or sulci aside. Smooth areas accompany the keel throughout. The primary ribs are strong and sharp and radiate to slightly prorsiradiate. The ribs are equal in thickness from the rounded umbilical edge up to the smooth area on the venter. Specimens reach a maximum diameter of approximately $90 \mathrm{~mm}$ (diagenetically flattened). On the large specimen (Fig. 8h), approximately 22 ribs can be counted on the last half whorl. The penultimate whorl appears with 17 ribs on half whorl. One specimen (Fig. 8i) appears with 19 ribs per half whorl at a diameter of $47 \mathrm{~mm}$ with 22 per half whorl at a diameter of $29 \mathrm{~mm}$. The innermost whorl on specimen Fig. 8 j shows 24 ribs per half whorl at a diameter of $14 \mathrm{~mm}$. The ribbing increases slowly but steadily. Rib spacing is 3-4 $\mathrm{mm}$ comparably wide on the final whorl. Both specimens (NHMW 2017/139/0024 and 0025; 8h and 8i) show a very low WER value of 1.47 , mirroring the slow increasing trend of whorl height growth within the final whorl. No suture line is visible. Our specimens are quite similar to the assemblage shown by Blau (1998) from the Austrian Lienz Dolomites. Blau (1998) reported three ontogenetical ribbing styles in his L. cf. macdonnelli: fine ribbed inner whorls, followed by a stage with very fine and weak rib and ending with prominent regular ribbing again. Blau (1998) interprets his L. cf. macdonnelli as a transitional form of L. meigeni (Hug) and "real" L. macdonnelli. L. cf. macdonnelli Blau (1998) might have a variation in ribbing, hence not be a different species. Therefore, we take it into synonymy.

\section{Measurements:}

\begin{tabular}{|c|c|c|c|c|c|c|c|c|c|c|c|}
\hline $\begin{array}{l}\text { Type/ } \\
\text { Inv. Nr. }\end{array}$ & $d$ & $h$ & $w$ & $u$ & ah & $h / w$ & $h / d$ & $h / u$ & $u / d$ & $w / d$ & WER \\
\hline $\begin{array}{l}\text { NHMW } \\
2017 / \\
0139 / \\
0024\end{array}$ & 91.32 & 20.35 & 6 & 48.10 & 16 & - & 0.22 & 0.42 & 0.53 & - & 1.47 \\
\hline $\begin{array}{l}\text { NHMW } \\
2017 / \\
0139 / \\
0029\end{array}$ & 50.40 & 11.50 & - & 30.90 & - & - & 0.23 & 0.37 & 0.61 & - & - \\
\hline $\begin{array}{l}\text { NHMW } \\
2017 / \\
0139 / \\
0025\end{array}$ & 42.87 & 10.45 & - & 26.14 & 7.54 & - & 0.24 & 0.40 & 0.61 & - & 1.47 \\
\hline
\end{tabular}

Occurrence and stratigraphic range: At the Tannscharten, L. gr. macdonnelli (Portlock, 1843) appears in beds 4-6, which are part of the E. raricostatum zone. L. macdonnelli occurs in the Tethyan realm in the late Sinemurian E. raricostatum zone (L. macdonnelli subzone; Schlegelmilch, 1976; Blau, 1998).

\section{Genus Paltechioceras Buckman, 1924}

Type of species: Paltechioceras elicitum Buckman, 1924; OD

\section{Paltechioceras boehmi (Hug, 1899) Fig 8k; Tab. 9}

*1899 Arietites Boehmi n. sp. - Hug, p. 16, pl. 12, figs. 8, $8 \mathrm{a}, \mathrm{b}$

1958 P. boehmi (Hug) - Donovan, p. 26, pl. 2, figs. 6a, b 1998 P. boehmi (Hug, 1899) - Blau, p. 208, pl. 4, fig. 9-20, pl. 5 , fig. 21

2003 P.? boehmi (Hug, 1899) - Edmunds et al., p. 70, fig. 4.1

2005 P. boehmi (Hug, 1899) - Tibuleac, p. 485, pl. 3, fig. 9

Number of specimens: Five specimens (NHMW 2017/0139/0030; BL 2017/0006-09) 
Description: The very evolute specimens show a fastigiate and rounded to subrounded early whorl section; later in ontogeny, elliptic and slightly compressed whorl section is seen. Keel is sharp and appears throughout ontogeny. Smooth areas (not sulci) run on both sides of the keel throughout. The densely primary ribs are strong, sharp and slightly curved and prorsiradiate in adult stages. The ribs are equal in thickness from the rounded umbilical edge, over the rounded flanks up to the smooth area on the venter. One specimen (NHMW 2017/0139/0030; $8 \mathrm{k}$ ) shows a low WER value of 1.46 mirroring the slow increasing trend of whorl height growth within the final whorl. Our specimens are quite similar to the ones from the Lienz Dolomites shown by Blau (1998), whose whorl growth is very slow. The juvenile specimen (NHMW 2017/0139/0030, Fig. 8k) shows 54 ribs on the last whorl (5th whorl). The average rib distance on the last whorl is $1.12 \mathrm{~mm}$. The final whorl depicts the body chamber marked by the last suture line. Specimen BL-Fahr-4 appears with 50 ribs and an average rib distance of $1.34 \mathrm{~mm}$. Blau (1998) states that specimens with $5-6 \mathrm{~cm}$ in diameter show about 54 ribs per whorl. Within the ontogeny of the lectotype of $P$. boehmi, the rib frequency increases from 42 (diameter $10 \mathrm{~mm}$ ) up to 53 (diameter $30 \mathrm{~mm}$ ) and 51 (diameter $45 \mathrm{~mm}$ ) ribs per whorl (Getty, 1973). Blau (1998) includes the specimens reported by Dommergues and Meister (1991) as P. boehmi into the synonymy of Paltechioceras favrei (Hug). This shows the difficulties in determination within the Paltechioceras group. Blau (1998) noted Plesechioceras delicatum Buckman, Paltechioceras rothpletzi (Böse) and Paltechioceras tardecrescens (Hauer) as exhibiting similar density in ribbing, with other specific species differences.

\section{Measurements:}

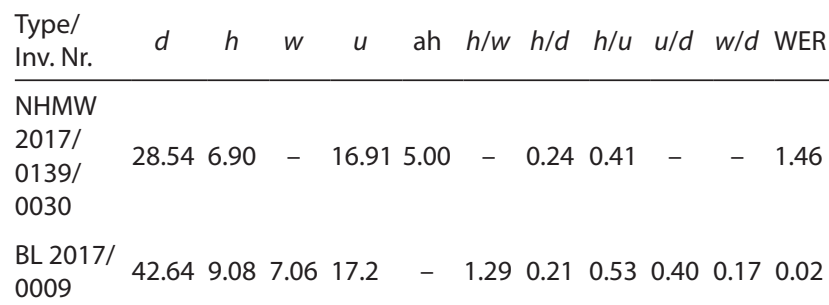

Occurrence and stratigraphic range: At the Tannscharten, P. boehmi occurs in beds 26-30, which are part of the E. raricostatum zone. P. boehmi appears in the Tethyan realm and Euroboreal realm in the late Sinemurian E. raricostatum zone (E. raricostatum subzone; Blau, 1998; Edmunds et al., 2003; Tibuleac, 2005).

\section{Paltechioceras oosteri (Dumortier, 1867)} Fig. 8I, m; Tab. 10

*1867 Ammonites oosteri - Dumortier, p.164, pl. 30, figs 3,4

1998 P. oosteri (Dumortier, 1867) - Blau, p. 213, pl. 10, figs. 14, 17, 19; pl. 14, fig. 2
2000 P. oosteri (Dumortier, 1867) - Blau et al., p. 267, figs. 11.4, 11.6, 11.7

2003 Paltechioceras ebriolum (T\&W) - Edmunds et al., p. 72 , fig. 6.4

Number of specimens: One specimen (BL 2017/0010) Description: The very evolute to advolute specimen shows an almost quadratic to rectangular whorl section. Keel is sharp and appears throughout ontogeny. The median keel on the rounded venter is accompanied by narrow furrows on both sides throughout ontogeny (= tricarinate and bisulcate). The ribs start from the rounded umbilical edge and run over the rounded flanks up to the less prominent and smaller side keels. The most specific and characteristic feature of $P$. oosteri is the irregularly preserved looping of ribs. This special rib morphology distinguishes $P$. oosteri from all other species (Blau et al., 2000). In our specimen, 4 looped rib pairs are observed on the last whorl. In specimen BL 2017/0010 (Fig. 8l, m) with a diameter of $36.63 \mathrm{~mm}, 44$ radial to slightly rursiradiate ribs (incl. looped ribs) were counted on the final whorl. The average rib distance is $2.32 \mathrm{~mm}$ on the last whorl. The penultimate whorl shows 34 widely spaced ribs. Rib distance is up to three times the rib thickness. Blau (1998) stated that ribs appear to swell at the ventral area and projected anteriorly. The present specimens are quite similar to the ones shown by Blau (1998) from the Lienz Dolomites. According to Blau (1998), P. oosteri differs from the most similar $P$. tardecrescens (Hauer) by the looping and swellings at the ventral ends of the ribs.

\section{Measurements:}

\begin{tabular}{lllllllllllllll}
$\begin{array}{l}\text { Type/ } \\
\text { Inv. Nr. }\end{array}$ & $d$ & $h$ & $w$ & $u$ & ah & $h / w$ & $h / d$ & $h / u$ & $u / d$ & $w / d$ & WER \\
\hline $\begin{array}{l}\text { BL 2017/ } \\
0010\end{array}$ & 36.63 & 9.55 & 7.40 & 20.22 & - & 1.29 & 0.26 & 0.47 & 0.55 & 0.20 & 0.03
\end{tabular}

Occurrence and stratigraphic range: At the Tannscharten, P. oosteri was not observed but has been found in the $E$. raricostatum zone of the nearby Fahrenberg locality (same syncline). P. oosteri occurs in the Tethyan realm and the Euroboreal realm in the late Sinemurian E. raricostatum zone (P. aplanatum subzone; Blau, 1998; Blau et al., 2000; Edmunds et al., 2003; Tibuleac, 2005). According to Blau (1998), P. oosteri is in the Lienz Dolomites and is the index species of the $P$. oosteri biohorizon.

\section{Late Sinemurian stratigraphy of the Tannscharten section}

The age and biostratigraphy of the marly and silicious limestones from the forest road at the Tannscharten were not known until now. On the geological map of Großraming (Geological map 69, 1:50,000; Egger and Faupl, 1999), the area is characterized by the occurrence of the Lower Jurassic Allgäu Formation. The ammonite assemblage includes the following late Sinemurian genera and species: P. striatocostatum (Meneghini), J. libertus (Gemmellaro), Paroxynoticeras sp., G. paniceum (Quenstedt), E. raricostatoides Vadász, E. quenstedti (Schafhäutl), L. 
meigeni (Hug), L. gr. macdonnelli (Portlock), P. boehmi (Hug) and P. oosteri (Dumortier). Ammonites are accompanied by two belemnite specimens, four brachiopods and one bivalve.

The ammonite species and resulting ammonite zones identified herein (based on index taxa and assemblages) for the Allgäu Formation allow a correlation of the late Sinemurian (O. oxynotum zone to E. raricostatum zone) strata at the Tannscharten and Fahrenberg localities with the recent standard zonation (Blau, 1998; Meister and Friebe, 2003; Ogg and Hinnov, 2012). If a particular zonal index ammonite is absent, the zonal boundary is interpreted by comparison with taxa that characterize the zone and its boundaries elsewhere (literature data) in the late Sinemurian (Lotharingian). The ammonite standard zones are recognised by the determination of the index ammonites at the Tannscharten fauna. Genera and species with known stratigraphical ranges (from other geographic areas) are compared with other well-known areas in the Tethyan realm and southern Boreal realm.

The occurring taxa and biostratigraphy are mainly matched to well-known and described faunas from Austria (Blau and Meister, 1991; Blau, 1998; Meister and Friebe, 2003), Germany (Schröder, 1927; Schlegelmilch, 1976; Blau, 1998), France (Dommergues and Meister, 1989), Switzerland (Schlatter, 1987), Romania (Tibuleac, 2005) and England (Edmunds et al., 2003).

The new ammonite data from the Tannscharten area correlate with reported other late Sinemurian assemblages from the Upper Austroalpine Units (Lienz Dolomites in East Tyrol and Carinthia, Southern Austria; Blau, 1998). Blau and Meister (1991) reported $P$. striatocostatum from the late Pliensbachian A. margaritatus zone of the Blasbründl locality (Lienz Dolomites). A precursor work to Blau (1998) and Blau and Grün (1995) was mostly dealing with lithofacies and microfossil descriptions on the Amlacher Wiesen Syncline in the Lienz Dolomites. The authors already mentioned the $E$. raricostatoides, P. boehmi, L. meigeniand L. macdonnellibiohorizons (Blau and Grün, 1995, p. 54), based on the occurrence of the index ammonites. The most extensive work on the same localities (23 genera and 46 species) was performed by Blau (1998) on late Sinemurian ammonites (A. obtusum, O.oxynotumand E.raricostatumzones) of the sameAllgäu Formation from the Lienz Dolomites. Identical faunal elements with the ones from Tannscharten are $P$. striatocostatum, J. libertus, Paroxynoticeras sp., G. paniceum (Gleviceras rigidum from Lienz Dolomites), E. raricostatoides, E. quenstedti, L. meigeni, L. gr. macdonnelli, P. boehmi and P. oosteri. Blau (1998) compared the assemblages from the Lienz Dolomites with additional faunas from the Northern Calcareous Alps, the Totes Gebirge Mountains (Austria) and the Chiemgau Alps and Ammergau Alps (both Germany). Within the Lienz Dolomites, the authors separated 17 local faunal biohorizons, with all of them in the E. raricostatum zone. The E. quenstedti,
E. raricostatoides, $P$. boehmi (E. raricostatum subzone), L. meigeni, L. macdonnelli (L. macdonnelli subzone) and $P$. oosteri ( $P$. aplanatum subzone) horizons are mainly marked by the first occurrence or range of the index ammonites, of which some occur also at the Tannscharten section. Hence, these biostratigraphic markers can be traced and correlated over wide distances as noted by Blau (1998). From the Totes Gebirge locality Rotkogel, E. raricostatum was reported (Schäffer and Steiger, 1986) and by Blau (1998), E. raricostatoides. Additional localities in the Allgäu Formation of the Totes Gebirge (Rettenbachmühle, with $E$. cf. raricostatum in Schäffer and Steiger, 1986, p. 61) and the Osterhorngruppe, Glasenbachklamm, yielded only few ammonite species such as $E$. raricostatum $(=A$. raricostatus in Vortisch, 1970, p. 148; Del-Negro, 1979).

Sinemurian and Plienbachian assemblages were documented from the Wundergraben section (Chiemgau Alps, Southern Germany) with E. raricostatum and L. macdonnelli ( $=$ Vermiceras raricostatus and $V$. cf. macdonnelli in Schröder, 1925, p. 263; Blau 1998; see also Langheinrich, 1967). Ganss (1956) reported from the same locality $E$. raricostatum and $L$. macdonnelli $(=$ V. raricostatus and V. cf. macdonnelli in Ganss, 1956, p. 20, fossil list of K. Hoffmann) in the Dampfgraben section and the Einfang section, respectively. Schröder (1925) noted additionally $P$. striatocostatum (= Phylloceras partschi Stur in Schröder, 1925, p. 262) and J. libertus (= R. libertus Gemm. in Schröder, 1925, p. 263) from the Tiefenbach locality near Ruhpolding. Sections of the Ammergau Alps (Southern Germany), the Pechkopf, the Weißer Rißkopf and the Klammgraben were reinvestegated by Blau (1998). The only co-occurring taxon between the Klammgraben and the Tannscharten is E. raricostatoides.

A similar fauna was reported by Jacobshagen (1963) from the lower Allgäu Formation (= Ältere Allgäu Schichten) of the western Northern Calcareous Alps (i.e. Wettersteingebirge, Lechtal Alps to Rhein river, Western Austria and Southern Germany). Especially, L. meigeni from the E. raricostatum zone at Gramais in the Lechtal Alps appears to be an identical element (Jacobshagen, 1963, p. 306). An extended version with additional ammonite lists was given in Jacobshagen (1965). Therein, L. meigeni was reported from the locality Seitekopf (northeast of Gramais, central Lechtal Alps), from the Holzgau Lermooser Syncline in the Haglertal valley at Häselgehr P. cf. boehmi (Hug). J. cf. libertus (Gemmellaro) was referred from the Bernhardstal valley at Unter-Gumpen. Additionally, J. libertus was mentioned from the Vilser Alps in the Tannheim valley (Besler, 1959; Jacobshagen, 1965). Besler (1959) listed numerous ammonite taxa from different localities of the Allgäu Formation of the Tannheim valley (Tyrol): the Wieslerbach section with L. macdonnelli $(=V$. macdonnelli Portl. in Besler 1959, p. 412) and J. libertus (= R. cf. libertus Gemm. in Besler 1959, p. 412) and the Steinabach bei Zöblen and Kienzerlebach with J. libertus (= R. libertus Gemm. in Besler 1959, p. 418, 420, 423). Besler (1959, p. 447) distinguished in the Lower Jurassic, a 
Vermicerasstufe ( $=E$. raricostatum zone), a biostratigraphic zone dominated by the occurrence of different echioceratid taxa (e.g. L. macdonnelli). This zone is most likely equivalent to the late Sinemurian.

Meister and Friebe (2003) reported several matching taxa from the Allgäu Formation of the Northern Calcareous Alps in Vorarlberg (Lechtal Nappe, W. Austria). P. gr. striatocostatum, J. libertus, E. gr. quenstedti and L. gr. meigeni were found at the Lorüns quarry, Rothorn, Eingemauerte, Goppelspitze and the Schröcken area.

Schröder (1927) described J. libertus (= R. libertus Gemm., p. 143) from the Lahngraben locality near Lenggries and L. macdonnelli (= V. macdonnelli Portl., in Schröder 1927, p. 183) from the Pech kopf near Hohenschwangau in the Bavarian Alps (Southern Germany). Additionally, several E. quenstedti (=Vermiceras var. quenstedti Schafh. in Schröder 1972, p. 188) and $P$. striatocostatum (= P. partschi, in Schröder 127, p. 122) were reported from these localities.

Koch and Stengel-Rutkowski (1959) reported similar faunas from the Lechtal Alps (Tyrol, Austria). From the lower Allgäu Formation (= Ältere Fleckenmergel in Koch et al., 1959) in the Krabachtal, L. cf. meigeni (Hug) was reported. From the area around the Wildhorn (East bank of lake Zürser See) in the Lechquellengebirge, $E$. (P.) sp. aff. boehmi (Hug) and numerous specimens of Leptechioceras, Paltechioceras and Echioceras are mentioned.

A single ammonite specimen, E. raricostatum (Zieten), was reported by Ehrendorfer (1988) from the Allgäu Formation near Großraming in the Frankenfels Nappe (Rettenbach Syncline).

Aberer (1951) noted a specimen of A. raricostatus Ziet. (=E. raricostatus) from east of Maria Neustift in Upper Austria ("Kriftergut" in the Frankenfels Nappe).

Getty (1973, p. 188, pl. 2, fig. 7; BS AS.IX.21) designated the lectotype for E. quenstedti (Schafhäutl) on a specimen from the Allgäu Formation (E. raricostatoides subzone) at the Kochelsee in the Northern Calcareous Alps (Bavarian Alps, Southern Germany). The neotype for E. raricostatoides (Vadász) was designated by Getty (1973, p. 13, pl. 1, fig. 12) from the E. raricostatoides subzone of the "Calcaire ocreux" from Seichamp near Nancy (Lorraine; École des Mines, Paris, Puzos Collection B14, 7).

Blau et al. (2000) described late Sinemurian and early Pliensbachian ammonite faunas from the HerfordDiebrock area (clay pit Stork 3, Northwest Germany). Therein, L. meigeni, L. macdonnelli (both L. macdonnelli/L. meigeni biohorizon; base of L. macdonnelli subzone) and $P$. oosteri ( $P$. tardecrescens biohorizon, base of $P$. aplanatum subzone) were figured. All the latter species form characteristic elements of the late Sinemurian in Northwest Germany and Austria with the locality Tannscharten in the Northern Calcareous Alps.

Edmunds et al. (2003) discussed the ammonite biostratigraphy of the late Sinemurian-early Pliensbachian at St Peter's Field (Radstock, Somerset, UK). The authors figured L. meigeni, P.? boehmi and L. macdonnelli. Additionally, a specimen of $P$. ebriolum was figured (p. 72, fig. 6.4), which is herein supposed to be a P. oosteri. Edmunds et al. (2003) stated that P. ebriolum is probably a pathological or mutational form of $P$. oosteri.

Schlegelmilch (1976) described from the Sinemurian of Southern Germany (Bempflingen, Baden-Württemberg) G. paniceum, from Southern England (Lyme Regis, Dorset) E. raricostatoides and from Ireland (Larne, Antrim) L. macdonnelli. Schlatter (1987) treated the species L. meigeni from the late Sinemurian of the Langeneckgrat locality (Thuner Alps, Préalpes médianes, Switzerland).

Dommergues and Meister (1989) reported on specimens from a late Sinemurian succession at Chablais méridional and Klippes des Savoie (Préalpes medians, Haute-Savoie, France). E. quenstedti, L. meigeni and P. boehmi (Mont Lachat de Châtillon and Le Môle) were figured.

Pia (1914) discussed the genus Oxynoticeras and mentioned the species G. paniceum (=0. paniceum, p. 33, pl. 6, fig. 3) from the late Sinemurian A. obtusum zone, figured originally by Quenstedt (1884) from Germany.

Tibuleac (2005) reported on new taxa from the olistolith of Praşca Peak (Rarău Syncline, Eastern Carpathians, Romania). He figured the late Sinemurian species E. raricostatoides, L. meigeni and $P$. boehmi.

Blau (1998) separated in the Allgäu Formation of the Lienz Dolomites within the E. raricostatum zone (E. raricostatum subzone) the E. quenstedti, the E. raricostatoides and the $P$. boehmi biohorizons (only those biohorizons were mentioned that can be correlated with the Tannscharten locality). The $E$. quenstedti biohorizon is characterized by the co-occurrence (only those species were noted that also occur at Tannscharte; for details see Blau, 1998) of E. quenstedti and J. libertus. Blau (1998) stated Echioceras as Euroboreal and J. libertus as Tethyan faunal element. The $E$. raricostatoides biohorizon is Euroboreal influenced and characterized by the co-occurrence of E. raricostatoides, Gleviceras sp. and J. libertus. The P. boehmi biohorizon is characterized by the co-occurrence of J. libertus, P. boehmi, P. striatocostatum and others. The dominant index species $P$. boehmi occurs in the Euroboreal and the Mediterranean realms. Tethyan elements are less common in that level. The L. macdonnelli subzone of the E. raricostatum zone include the L. meigeni and L. macdonnelli biohorizons. The L. macdonnelli biohorizon is characterized by the co-occurrence of J. libertus, L. macdonnelli, L. meigeni, P. striatocostatum and others. The dominating genus Leptechioceras is an Euroboreal element and co-occurs with the Tethyan genera Juraphyllites and Partschiceras. The L. meigeni biohorizon is characterized by the co-occurrence of J. libertus, L. macdonnelli, L. meigeni and others. In accordance to Blau (1998), we follow the idea that L. macdonnelli appears later than L. meigeni. The P. aplanatum subzone of the $E$. raricostatum zone includes the $P$. oosteri biohorizon. The $P$. oosteri biohorizon is characterized by the co-occurrence of J. libertus, P. oosteri, P. striatocostatum and others. The biohorizon is dominated by Tethyan faunal elements. G. paniceum can be observed in the 
O. oxynotum zone. It presumably can be correlated with the G. rigidum biohorizon of Blau (1998). G. paniceum seems to be restricted to the Tethyan realm (i.e. Alpine area), as stated also for G. rigidum (Blau, 1998).

The presented data from the Tannscharten locality allow a more precise reconstruction of the palaeogeographic setting of the studied section. Accordingly, the described specimens were found in deep-water deposits of the Allgäu Formation basin situated on the Lower Jurassic Adriatic (Alpine-Apennine) Plate (Fourcade et al., 1993; Lukeneder, 2010) of the western Tethys.

The studied locality offers one of the few opportunities to investigate Upper Sinemurian ammonite faunas. Hence, the Tannscharten section represents a key locality for a detailed investigation of an ammonite fauna affected by an environmental turnover (i.e. drowning and deepening). The almost worldwide distribution of Lower Jurassic (e.g. Sinemurian) pelagic to hemipelagic ammonites during that time makes these cephalopods suitable for biostratigraphic correlations within the Tethyan realm. In the case of the Tannscharten assemblage, a mix of Euroboreal and Mediterranean elements is observed. The ammonite fauna from Tannscharten mirrors the connective palaeoceanographic position of the basinal area of the Austroalpine Units on the northern end of the Alpine-Apennine Plate in the Lower Jurassic.

\section{Conclusions}

The so far undescribed macrofauna of the Tannscharten section (Reichraming Nappe, Northern Calcareous Alps) is mainly represented by ammonites, scarce belemnites and brachiopods. A total of 46 ammonite specimens, four belemnites and two brachiopods were collected and supplemented by nine ammonites and one brachiopod from the Fahrenberg section (to the east in Schneeberg Syncline).

During the deposition of the Tannscharten sequence, a significant facies change took place - from the shallow-water deposits of the Rhaetian oolites and red limestones of the Adnet Formation to the deep-water marly limestones and limestones of the Lower Jurassic Allgäu Formation (="Lias Fleckenmergel").

J. libertus, P. striatocostatum, G. paniceum, E. quenstedti, E. raricostatoides, $P$. boehmi, L. meigeni, L. macdonnelli and $P$. oosteri are described for the first time from the Schneeberg Syncline. The most abundant genus in this section is Leptechioceras (51.6\%) followed by Echioceras (25.8\%), Paltechioceras (6.5\%), Gleviceras (6.5\%), Juraphyllites (3.2\%), Paroxynoticeras (3.2\%) and Partschiceras (2.2\%). An additional fauna from the nearby Fahrenberg section is represented by Paltechioceras (50\%), Leptechioceras (40\%) and Juraphyllites (10\%).

The ammonite assemblage points to a late Sinemurian age (upper part of the O. oxynotum zone to the middle part of the $E$. raricostatum zone). Several zones and even subzones, especially biohorizons, based on the presence of index ammonites - such as E. quenstedti, E. raricostatoides, P. boehmi, L. meigeni, L. macdonnelli and
P. oosteri biohorizons - were detected. The biohorizons subsequently fix the presence of the E. raricostatum, L. macdonnelli and P. aplanatum zones. When the index species are missing, the zones are characterized by their typical ammonite associations. The fossiliferous deposits start with the $G$. paniceum beds of the late Sinemurian O. oxynotum zone (O. oxynotum subzone), and they end with the late Sinemurian occurrence of $P$. oosteri in the E. raricostatum zone ( $P$. aplanatum subzone).

The ammonite assemblage clearly indicates the Mediterranean Province (Austria, Southern Germany and Italy) with influences of the Northwest European Province (United Kingdom, Ireland, France, Germany, Switzerland).

Ammonite specimens from the younger part of the Tannscharten section point to be part of the E. raricostatum zone (E. raricostatoides subzone). Although, there are some fossils with long stratigraphic ranges (e.g. J. libertus, P. striatocostatum), only G. paniceum can be assigned to be older and a constituent of the upper part of 0 . oxynotum zone.

\section{Acknowledgements}

We are grateful to Joachim Blau (Frankfurt) for the revision and validation of ammonite determination and Luka Gale (Ljubljana) for the determination of foraminifera. Our sincere thanks go to Berthold Lumplecker (Großraming) for providing ammonite specimens. We are particularly grateful to Roland Mayer, Franz Mayer and Anton Englert (all from Vienna) for the production of thin sections. Thanks go to Martin Maslo who reported to us the important Tannscharten area. We wish to thank Maximilian Kautsch (Reichraming) for a driving and digging permit for his forest road to the Tannscharten section. The manuscript greatly benefited from two reviews by Joachim Blau (Frankfurt) and Leopold Krystyn (Vienna). This work is dedicated to Lisa Marie Lukeneder (Gablitz) who inspires us every day.

\section{References}

Aberer, F., 1951. Beiträge zur Stratigraphie und Tektonik der Randzonen der nördlichen Kalkalpen zwischen Neustift und Konradsheim. Mitteilungen der Geologischen Gesellschaft in Wien, 39-41 (1946-1948), 1-73.

Austromap Online 2017. Bundesamt für Eich- und Vermessungswesen, Wien. http://www.austrianmap.at/ amap/index.php?SKN=1\&XPX=637\&YPX=492, accessed 11 November 2017.

Bernoulli, D. and Jenkyns, H.C., 1970. A Jurassic Basin: the Glasenbach gorge, Salzburg, Austria. Verhandlungen der Geologischen Bundesanstalt, 1970, 504-531.

Besler, W., 1959. Die Jura-Fleckenmergel des Tannheimer Tales (Außerfern, Tirol). Jahrbuch der Geologischen Bundesanstalt, 102, 407-460.

Blau, J., 1998. Monographie der Ammoniten des Obersinemuriums (Lotharingium, Lias) der Lienzer Dolomiten (Österreich): Biostratigraphie, Systematik 
und Paläobiogeographie. Revue de Paléobiologie, 17/1, 177-285.

Blau, J. and Grün, B., 1995. Jura und Kreide in der AmlacherWiesen-Mulde(NördlicheLienzerDolomiten). Arbeitstagung der Geologischen Bundesanstalt. Geologie von Osttirol, Lienz 1995, 43-66.

Blau, J. and Meister, C., 1991. Liassic (Pliensbachian) ammonites from the Lienz Dolomites (Eastern Tyrol, Austria). Jahrbuch der Geologischen Bundesanstalt, 134, 171-204.

Blau, J. and Meister, C., 2000. Upper Sinemurian Ammonite Successions Based on 41 Faunal Horizons: an Attempt at Worldwide Correlation. In: Hall, R.L. and Smith, P.L. (eds) Advances in Jurassic Research. GeoResearch Forum, 6, 3-12.

Blau, J, Meister, C., Ebel, R., Schlatter, R., 2000. Upper Sinemurian and Lower Pliensbachian ammonite faunas from Herford-Diebrock area (NW Germany). Paläontologische Zeitschrift, 74/3, 259-280. https://doi. org/10.1007/BF02988101

Blau, J., Meister, C., Schlatter, R. and Schmidt-Effing, R., 2003. Ammonites from the Lower Jurassic (Sinemurian) of Tenango de Doria (Sierra Madre Oriental, Mexico). Part III: Echioceratidae. Revue de Paléobiologie, 22/1, 421-437.

Böhm, F., 1992. Mikrofazies und Ablagerungsmilieu des Lias und Dogger der Nordöstlichen Kalkalpen. Erlanger Geologische Abhandlungen, 121, 57-217.

Böhm, F., Ebli, O., Krystyn, L., Lobitzer, H., Rakús and Siblík, M., 1999. Fauna, Stratigraphy and Depositional Environment of the Hettangian-Sinemurian (Early Jurassic) of Adnet (Salzburg, Austria). Abhandlungen der Geologischen Bundesanstalt, 56/2, 143-271.

Braga, J.C. and Rivas, P., 1987. Phylloceratidae del Lias Medio de la Zona Subbettica. Boletín de la Real Sociedad Española de Historia Natural (Sessión geológica), 82, 65-86.

Del-Negro, W., 1979. Erläuterungen zur geologischen Karte der Umgebung der Stadt Salzburg, 1:50000, 1-41. Dommergues, J.-L., Dommergues, C.H. and Meister, C., 2006. Exploration of the Oxynoticeratidae ornamental morphospace using the discrete cosine transform (DCT) to analyze rib patterns. Paleobiology, 32/4, 628-651. https://doi.org/10.1666/05046.1

Dommergues, J.-L. and Meister, C., 1989. Succession des faunes d'Ammonites du Sinémurian supérieur dans le Chablais meridional et les Klippes des Savoie (Préalpes medians, Haute-Savoie, France). Geobios 22/4, 455-483. https://doi.org/10.1016/S0016-6995(89)80099-3

Donovan, D.T., 1958. Révision des espèces décrites dans la «Monograophie des Ammonites» (Lias inférieur) de P. Reynes. Mémoires de la Société géologique de France (nouvelle série), 73, 1-47.

Edmunds, M., Varah, M. and Bentley, A., 2003. The ammonite biostratigraphy of the Lower Lias "Armatum Bed" (Upper Sinemurian-Lower Pliensbachian) at St Peter's Field, Radstock, Somerset. Proceedings of the Geologist's Association, 114, 65-96. https://doi.org/10.1016/ S0016-7878(03)80028-7
Egger, H., 1988. Zur Geologie der Kalkvoralpen im östlichen Oberösterreich. Jahrbuch der Geologischen Bundesanstalt, 132/2, 245-254.

Egger, H. and Faupl, P., 1999. Geological map of Austria, 1:50.000, sheet 69 Grossraming. Geologische Bundesanstalt, Wien.

Egger, H. and van Husen, D., 2011. Erläuterungen zu Blatt 69 Grossraming. Geologische Karte der Republik Österreich 1:50 000. Geologische Bundesanstalt Wien, 1-115.

Ehrendorfer, T., 1988. Zur Geologie der Weyerer Bögen im Gebiet von Großraming an der Enns (O.Ö.). Mitteilungen der Gesellschaft der Geologie- und Berbaustudenten Österreichs, 34/35, 135-149.

Fourcade, E., Azema, J., Cecca, F., Dercourt, J., Guiraud, R., Sandulescu, M., Ricou, L.-E., Vrielynck, B., Cottereau, N. and Petzold, M., 1993. Late Tithonian (138 to $135 \mathrm{Ma}$ ). In: Dercourt, J., Ricou, L.E. and Vrielynck, B (eds) Atlas Tethys Palaeoenvironmental Maps. BEICIP-FRANLAB, Rueil-Malmaison.

Ganss, O., 1956. Geologie des Blattes Bergen. Geologica Bavarica, 26, 1-164.

Getty, T.A., 1973. A Revision of the generic classification of the family Echioceratidae (Cephalopoda, Ammonoidea) (Lower Jurassic). Paleontological Contributions, 63, 1-32. Geyer, G., 1910. Aus den Kalkalpen zwischen dem Steyrund dem Almtale in Oberösterreich. Verhandlungen der Kaiserlich Königlichen Geologischen Reichsanstalt, 1910, 169-195.

Jacobshagen, V., 1963. Lias und Dogger im WestAbschnitt der Nördlichen Kalkalpen. Geologica Romana, 3, 303-318.

Jacobshagen, V., 1965. Die Allgäu-Schichten (JuraFleckenmergel) zwischen Wettersteingebirge und Rhein. Jahrbuch der Geologischen Bundesanstalt, 108, 1-114.

Joly, B., 2000. Les Juraphyllitidae, Phylloceratidae, Neophylloceratidae (Phyllocerataceae, Phylloceratina, Ammonoidea) de France au Jurassique et au Crétacé. Mémoire Spécial Geobios 23, Mémoire de la Société Géologique de France, 174, 5-204. https://doi. org/10.1016/S0016-6995(00)80001-7

Klug, C., 2001. Life-cycles of some Devonian ammooids. Lethaia, Vol. 34, 215-233. https://doi. org/10.1111/j.1502-3931.2001.tb00051.x

Koch, K. E. and Stengel-Rutkowski, W., 1959. Faziesuntersuchungen in Jura und Unterkreide der westlichen Lechtaler Alpen. Verhandlungen der Geologischen Bundesanstalt, 1959/2, 179-201.

Korn, D., 2000. Morphospace occupation of ammonoids over the Devonian-Carboniferous boundary. Paläontologische Zeitschrift, December 2000, Volume 74, Issue 3, 247-257. https://doi.org/10.1007/BF02988100

Langheinrich, G., 1967. Die Bestimmung der tektonischen Gesteinsdeformation mit Hilfe deformierter Ammoniten; mit zwei Beispielen aus den Allgäu-Schichten (Jura-Fleckenmergel) Oberbayerns und Tirols. Neues Jahrbuch für Geologie und Paläontologie, Abhandlungen. 128/3, 275-293. 
Lukeneder, A., 2004. A Barremian ammonoid association from the Schneeberg Syncline (Early Cretaceous, Northern Calcareous Alps, Upper Austria). Annalen des Naturhistorischen Museums Wien, 106A, 33-51.

Lukeneder, A., 2010. Lithostratigraphic definition and stratotype for the Puez Formation: formalisation of the Lower Cretaceous in the Dolomites (S. Tyrol, Italy). Austrian Journal of Earth Sciences, 103/1, 138-158.

Meister, C. and Friebe, J.G., 2003. Austroalpine Liassic Ammonites from Vorarlberg (Austria, Northern Calcareous Alps). Beiträge zur Paläontologie, 28, 9-99.

Müller, A.M., 1987. Bericht 1986 über geologische Aufnahmen in den Kalkalpen auf Blatt 69 Großraming. Jahrbuch der Geologischen Bundesanstalt, 130, 282-284.

Ogg, J.G. and Hinnov, L.A., 2012. Jurassic. In: Gradstein, F.M., Ogg, J.G., Schmitz, M.D. and Ogg, G.M. (eds) The Geologic Time Scale, 731-791.

Page, K.N., 2003. The Lower Jurassic of Europe: it's subdivision and correlation. Geological Survey of Denmark and Greenland Bulletin, 1, 23-59.

Piller, W.E., Egger, H., Erhart, C.W., Gross, M., Harzhauser, M., Hubmann, B., van Husen, D., Krenmayr, H.-G., Krystyn, L., Lein, R., Lukeneder, A., Mandl, G., Rögl, F., Roetzel, R., Rupp, C., Schnabel, W., Schönlaub, H.P., Summesberger, H. and Wagreich, M., 2004. Die Stratigraphische Tabelle von Österreich 2004 (sedimentäre Schichtfolgen). Kommission für die Paläontologische und stratigraphische Erforschung Österreichs. Österreichische Akademie der Wissenschaften und Österreichische Stratigraphische Kommission, Wien.

Plöchinger, B. and Karanitsch, P., 2002. Faszination Erdgeschichte mit Brennpunkt Mödling am Alpenostrand. Heimat Verlag, 11-238.

Quenstedt, F.A., 1884. Die Ammoniten des schwäbischen Jura, 1 Band. Der schwarze Jura (Lias). Schweizerbart, Tübingen, 1-440.

Rakús, M., 1999. Some hitherto undescribed Liassic ammonites from the Adnet Formation in Austria. Abhandlungen der Geologischen Bundesanstalt, 56/2, 319-328.

Reid, C.G.R. and Bancroft, A.J. 1986. The Irish Lower Jurassic Type Ammonites of Major-General J.E. Portlock (1843): Leptechioceras macdonnelli, Psiloceras (Caloceras) intermedium, and Psiloceras (Psiloceras) sampsoni. Irish Journal of Earth Sciences 8(1), 41-51. https://www.jstor.org/stable/30002259

Schäffer, G. and Steiger, T., 1986. Stratigraphie und Gleitmassen in Tiefwassersedimenten der Nördlichen Kalkalpen. Exkursionsführer zur Jahrestagung der Subkommisssion für Jura-Stratigraphie. München-Salzburg-Bad Aussee, $1-67$.

Schlegelmilch, R., 1976. Die Ammoniten des süddeutschen Lias. 2. Auflage. Gustav Fischer Verlag, 1-212. Schlatter, R., 1987. Beiträge zu den Arietitinae (Ammonoidea) aus dem Lotharingian vom Langeneckgrat (Thuner Alpen, Préalpes médianes). Eclogae geologica Helvetiae, 80/3, 1119-1127.
Schlatter, R., 1991. Biostratigraphie und Ammonitenfauna des Ober-Lotharingium und Unter-Pliensbachium im Klettau (Kanton Schaffhausen, Schweiz) und angrenzender Gebiete. Anhandlungen der Schweizerische Paläontologische Gesellschaft, 113, 1-133.

Schröder, J., 1925. Die jurassische Formation der bayrischen Alpen. Neues Jahrbuch für Mineralogie und Paläontologie, Beil. Band 52, 214-283.

Schröder, J., 1927. Die Ammoniten der jurassischen Fleckenmergel in den bayrischen Alpen. Teil 1. Palaeontographica, A 68, 112-232.

Țibuleac, P., 2005. New Data about the Age and the Stratigraphical Position in the Cretaceous Wildflish of the Olistolith from Praşca Peak (Rarău Syncline, Eastern Carpathians, Romania). Acta Palaeontologica Romaniae, 5/2005, 483-491.

Tollmann, A., 1976. Analyse des klassischen nordalpinen Mesozoikums. Franz Deuticke Wien, 1-580.

Tollmann, A., 1985. Geologie von Österreich. Band 2, Außerzentralalpiner Anteil. Franz Deuticke Wien, $1-710$.

Tomas, R. and Pálfy, J., 2007. Revision of Early Jurassic ammonoid types from the Persani Mts. (East Carpathians, Romania). Neues Jahrbuch für Geologie und Paläontologie Abhandlungen, 243, 231-254. https://doi.org/10.1127/0077-7749/2007/0243-0231

Vašíček, Z. and Faupl, P., 1999. Zur Biostratigraphie der Schrambachschichten in der Reichraminger Decke (Unterkreide, oberösterreichische Kalkalpen). Abhandlungen der Geologischen Bundesanstalt, 56/2, 593-624.

Vortisch, W., 1970. Die Geologie des Glasenbachtales südlich von Salzburg. Geologica et Palaeontologica, 4, 147-166.

Wiedenmayer, F., 1977. Die Ammoniten des Besazio-Kalks (Pliensbachian, Südtessin). Schweizerische Paläontologische Abhandlungen, 98, 1-131.

Wissner, U., 1958. Ammonitenfauna und Stratigraphie der Lias-Fleckenmergel, Sinemurian bis Domerian in den Bayerischen Alpen. PhD Thesis, University Tübingen, 1-150.

Received: 28122017

Accepted: 18052018

\footnotetext{
Petra LUKENEDER ${ }^{1 * *}$ \& Alexander LUKENEDER ${ }^{1)}$

${ }^{1)}$ Museum of Natural History Vienna, Burgring 7, 1010 Vienna, Austria;

*) Corresponding author: petra.lukeneder@gmx.at
} 